\title{
Labor Regulations and European Venture Capital
}

\section{Citation}

Bozkaya, Ant, and William R. Kerr. "Labor Regulations and European Venture Capital." Journal of Economics \& Management Strategy (forthcoming).

\section{Permanent link}

http://nrs.harvard.edu/urn-3:HUL.InstRepos:10685087

\section{Terms of Use}

This article was downloaded from Harvard University's DASH repository, and is made available under the terms and conditions applicable to Open Access Policy Articles, as set forth at http:// nrs.harvard.edu/urn-3:HUL.InstRepos:dash.current.terms-of-use\#OAP

\section{Share Your Story}

The Harvard community has made this article openly available.

Please share how this access benefits you. Submit a story.

Accessibility 


\title{
Labor Regulations and European Venture Capital ${ }^{*}$
}

\author{
Ant Bozkaya ${ }^{\dagger} \quad$ William R. Kerr ${ }^{\ddagger}$
}

January 2013

\begin{abstract}
European nations substitute between employment protection regulations and labor market expenditures (e.g., unemployment insurance benefits) for providing worker insurance. Employment regulations more directly tax firms making frequent labor adjustments than other labor market insurance mechanisms. Venture capital investors are especially sensitive to these labor adjustment costs. Nations favoring labor market expenditures as the mechanism for providing worker insurance developed stronger venture capital markets over 1990-2008, especially in high volatility sectors. In this context, policy mechanisms are more important than the overall level of worker insurance.
\end{abstract}

JEL Classification: G24, J21, J65, L26, M13, O31, O32, O52.

Key Words: employment protection regulations, dismissal costs, unemployment insurance benefits, private equity, venture capital, entrepreneurship.

${ }^{*}$ The authors are grateful to the European Private Equity and Venture Capital Association for providing data; to David Autor, Eric Bartelsman, Lewis Branscomb, Björn Brügemann, Marco Da Rin, Shihe Fu, Thomas Hellmann, David Hsu, Karlo Kauko, Sari Kerr, Josh Lerner, Mika Maliranta, Matt Marx, Ramana Nanda, Petri Rouvinen, Raffaella Sadun, Olav Sorenson, Tuomas Takalo, Bruno van Pottelsberghe, Jusso Vanhala, Niels Westergård-Nielsen, Rebecca Zarutskie, an Associate Editor and two referees, and seminar participants at the Bank of Finland, Dubai School of Government, European Productivity Conference, European Regional Science Association, Harvard University, MIT Sloan, National Bureau of Economic Research, and Universite Libre de Bruxelles for helpful comments; and to Harvard Business School and the Innovation Policy and the Economy group for financial support. Kerr is a research associate of the Bank of Finland and thanks the Bank for hosting him during a portion of this research. The research in this paper was conducted while the authors were Special Sworn Status researchers of the U.S. Census Bureau at the Boston Census Research Data Center (BRDC). Support for this research from NSF grant (ITR-0427889) is gratefully acknowledged. Research results and conclusions expressed are our own and do not necessarily reflect the views of the Census Bureau or NSF. This paper has been screened to insure that no confidential data are revealed. An earlier version of this paper was titled "Labor Regulations and European Private Equity."

${ }^{\dagger}$ MIT; bozkaya@mit.edu; MIT Sloan, 50 Memorial Drive, Cambridge, MA 02142, USA.

${ }^{\ddagger}$ Harvard University, Bank of Finland, and NBER; wkerr@hbs.edu; Rock Center 212, Harvard Business School, Boston, MA 02163, USA. 


\section{Introduction}

Policy makers and business leaders are continually seeking ways to foster innovation and economic growth in their regions. A common refrain is that attracting venture capital (VC) investors is an important early step. Both the European Union and OECD are urging member states to promote the availability of risk capital financing for entrepreneurs, and multiple European governments are investigating how to support VC and entrepreneurial ecosystems. These efforts are encouraged by more than just flashy case studies of Silicon Valley. These investors are linked to better performance of portfolio companies and stronger aggregate innovation and growth. ${ }^{1}$

This paper investigates how labor market regulations across European countries influence the development of $\mathrm{VC}$ investors. We focus specifically on policy choices that provide labor market insurance to workers. European countries differ substantially in whether they emphasize stronger employment protection versus greater unemployment insurance benefits as techniques for providing worker insurance. Our analysis examines the joint effects of these policies on the types and strengths of $\mathrm{VC}$ investments made. We find evidence that strict labor regulations hinder VC investment, especially in sectors with high labor volatility (e.g., computers).

Figure 1a illustrates the central policy trade-off that we evaluate by plotting labor market expenditures (e.g., unemployment insurance benefits, worker re-training) against an index of employment protection. First, Anglo-Saxon countries provide lower worker insurance on both dimensions than Continental Europe. These differences in absolute levels of worker insurance provided by nations have been a frequent political economy topic since at least de Tocqueville. Second, the solid trend line, which is calculated only for Continental European nations and excludes the Anglo-Saxon countries, indicates that economies with higher labor market expen-

\footnotetext{
${ }^{1}$ For example, Kortum and Lerner (2000), Samila and Sorenson (2011b), and Kerr et al. (2012).
} 
ditures have weaker employment protection. These mechanism differences have received less attention, but the empirical policy substitution is clear (e.g., the Danish "flexicurity" approach). The dashed trend line excludes Switzerland, whose policies more closely resemble Anglo-Saxon economies, showing an even more pronounced substitution.

While employment protection and transition/re-entry assistance are perhaps substitutes for providing worker security, they have different implications for the costs firms face. Employment protection taxes the labor adjustment margins of firms, and these adjustment costs can deter VC investors given their attraction to growing, volatile sectors and given the business model that VC investors employ. While labor market regulations do not specifically target VC-backed companies, these investors are seeking opportunities that are generally more sensitive to these taxes on labor adjustment. Figures 1c and 1d show that policy choices are correlated with VC placement (trend lines are still for Continental Europe). This study investigates these macrocorrelations more systematically through a country-sector panel analysis.

Our study makes three important contributions. Despite a large theoretical literature on labor market policies, there are very few empirical studies that consider multiple labor insurance mechanisms. Blanchard and Wolfers (2000) provides the first and most comprehensive empirical analysis of multiple labor policies in a study of the determinants of European unemployment, but there has been little empirical work since then. Our first contribution builds upon Blanchard and Wolfers (2000) by designing statistical tests that take account of substitution across different mechanisms. We also develop simple transformations of the base policies to separate the general level of labor market insurance provided to workers (aggregating over policies) and the policy mechanisms used to implement the insurance. These methodologies help distinguish and emphasize the roles and importance of labor insurance policy mechanisms. 
Second, recent theoretical models predict that countries with stricter labor policies will specialize in less-innovative activities due to the higher worker turnover frequently associated with rapidly changing sectors. We use this prediction to provide greater empirical identification than prior work. We analyze how policies impact 1) the cross-sectional distribution of sector-level investments over countries similar to the Rajan and Zingales (1998) methodology, 2) an aggregate longitudinal response within countries similar to Blanchard and Wolfers (2000), and 3) a differential longitudinal response across sectors within a country that is akin to a differencing of these methodologies. With respect to the first approach, we follow Klapper et al. (2006) who use U.S. industry-level conditions to quantify the importance of entry barriers for entrepreneurship across Europe in a Rajan and Zingales (1998) framework. Our paper is the first in the entrepreneurial finance literature to conduct this type of country-sector analysis for labor market insurance policies. Our paper is also the first to undertake triple-differencing estimations that push the Rajan and Zingales (1998) framework to also capture longitudinal changes.

Our final contribution is to document several new features on European VC investment and portfolio companies. Most important, we provide the first systematic evidence on higher rates of labor volatility among European firms backed by VC investors compared to their peers. We also show how VC selection differs by country-sector conditions as discussed further below.

A better understanding of these labor market insurance issues is essential for business managers and policy makers. Despite a general desire to promote high-growth entrepreneurship, there is substantial ambiguity about how to measure entrepreneurship and uncertainty about which policy levers are best utilized. With respect to measurement, self-employment indices are often utilized by academics and practitioners, and this metric might lead one to conclude that employment protection increases entrepreneurship, as countries with stricter labor policies often 
have higher self-employment rates. Our work shifts the focus, however, to VC investments and high-growth entrepreneurship where the opposite pattern is evident even in the raw data- e.g., southern European countries top self-employment scales but have smaller VC markets; the opposite is true for Scandinavia. ${ }^{2}$ Our study provides a more accurate empirical depiction of how labor market policies influence innovation and high-growth entrepreneurship than previously available. Establishing these facts is key for investment and firm location decisions (e.g., Alcacer and Chung 2007), cluster formation (e.g., Delgado et al. 2010a,b, Glaeser et al. 2012), and appropriate policy design.

Related to the uncertainty about which policy levers to utilize, many countries attempt active policy interventions, like public venturing, to promote entrepreneurship (Leleux and Surlemont 2003). Yet many of these active efforts are unsuccessful (e.g., Lerner 2009). Our work instead highlights the strong influence of passive policies like general labor regulations. ${ }^{3}$ Moreover, the sector-level specialization that we document is very important for VC placement decisions given the cluster and agglomeration economics typical of this sector. Public venturing is unlikely to be successful, for either the policy maker or business manager induced to enter, if the underlying policy environment is inappropriate. Interventions often target volatile sectors (e.g., energy, computers, biotech), yet our sector-level placement work shows that VC investments for these sectors are most influenced by the mechanism choice.

Finally, this study contributes to work on how labor market regulations influence industrial structure and productivity growth. Many observers believe strict European labor policies hinder

\footnotetext{
${ }^{2}$ Definitions of entrepreneurship matter a lot in this context, with self-employment often reflecting poor opportunities (e.g., Glaeser and Kerr 2009, Schoar 2009, and Åstebro et al. 2011). Parker (2009) provides a comprehensive review of the literature on entrepreneurship.

${ }^{3}$ This complements studies of non-compete clauses that are far more prevalent (e.g., Gilson 1999, Hyde 2003, Stuart and Sorenson 2003, Fallick et al. 2005, Armour and Cumming 2006, Franco and Mitchell 2008, Marx et al. 2009a,b, Samila and Sorenson 2011a,b). Ardagna and Lusardi (2009) provide a broader scope on regulations.
} 
economic growth, perhaps by redirecting or slowing down innovation and start-up entry, reducing the speed at which scarce resources are reallocated towards more productive opportunities, and similar. A recent Economist article, for example, cited labor regulations as one of the three big factors holding European entrepreneurship back, along with bankruptcy provisions/fear of failure and access to finance. ${ }^{4}$ Our study of VC investments provides an input into understanding these questions with particular attention placed on the differences that emerge across European sectors in response to policy frameworks and managerial choices.

\section{Theoretical Background and Empirical Approach}

\section{Employment Protection and Labor Volatility}

A vast theoretical literature considers the economic effects of employment protection. These models differ sharply with respect to how employment protection influences total employment levels, technical efficiency, and many other economic outcomes. Our study, however, focuses on one economic outcome where the models share a common finding - that employment protection should dampen labor fluctuations by firms when binding. If not binding, perhaps because the value that workers place on employment protection exactly offsets costs to firms, then no changes in labor fluctuations should be observed. Otherwise, employment protection results in labor adjustment costs to firms that reduce job separations. Moreover, if firms are forward-looking and anticipate these separation costs, they reduce their hiring rates as well. While the net effect of this reduced hiring and firing is ambiguous for many outcomes like firm productivity, overall employment volatility unambiguously declines. ${ }^{5}$

\footnotetext{
4 "Les misérables", Briefing on European Entrepreneurs, 28 July 2012, 19-22.

${ }^{5}$ Empirical evidence, while small, supports this prediction of dampened firm volatility due to stricter employment protection (e.g., Blanchard and Portugal 2001, Autor et al. 2007, Lafontaine and Sivadasan 2009, and Wolfers 2010). Addison and Teixeira (2003) provide a more comprehensive review.
} 
This labor adjustment cost feature of employment protection contrasts sharply with labor market expenditures (e.g., unemployment insurance benefits) that also provide worker insurance but do not tax separations directly. Thus, firms have greater flexibility in their hiring and firing if worker insurance is provided through labor market expenditures. General taxation may need to be higher to support labor market expenditures, but this taxation is shared throughout the economy, rather than concentrated on one margin. ${ }^{6}$ Thus, firms and industries with high inherent labor volatility are disadvantaged, all else being equal, when labor market insurance is provided to workers via employment protection rather than through labor market expenditures. Despite the theoretical work examining each policy separately, we are just beginning to model and evaluate their optimal design jointly. Optimal design may involve both policies to a degree, and there are many factors beyond our study's scope. We hope to provide empirical evidence from VC placements that informs this important policy trade-off. ${ }^{7}$

\section{Venture Capital Investments}

Young entrepreneurial firms often struggle with financing the pursuit of their innovations or business concepts (e.g., Cabral and Mata 2004). These start-ups have few tangible assets that can be pledged for a bank loan, and traditional financial institutions typically lack the expertise to assess the creditworthiness of proposed ventures, especially in emerging sectors. VC investors have emerged as an effective model for financing and supporting these innovative, high-growth opportunities.

There are two general ways in which strict employment protection impacts VC investors.

\footnotetext{
${ }^{6}$ Experience Rating systems link unemployment insurance contributions to dismissal histories (a partial incidence weaker than employment protection). This system is employed by the US but otherwise fairly rare.

${ }^{7}$ Examples of joint policy models are Pissarides (2001), Blanchard and Tirole (2007), Brügemann (2007), and Boeri et al. (2010). Alesina et al. (2001) and Kerr (2011) further discuss the higher general worker insurance levels provided by Continental European countries compared to Anglo-Saxon economies.
} 
First, employment protection hinders the overall development of the high-growth sectors in which VCs specialize, due to its tax on worker dismissals. This market size effect is particularly acute in high-volatility industries that are often associated with technical change. This sectorlevel prediction is more subtle than the general prediction of declining employment fluctuations noted above for the whole economy. ${ }^{8} \mathrm{VC}$ investors are very sensitive to this weakening of highgrowth, volatile industries. Growing sectors aid the rapid development of portfolio companies. Moreover, many screening, monitoring, and reputation features of the value-added VC model are most beneficial in these settings of incomplete information and uncertainty (e.g., Hsu 2004). VC-backed firms are linked with the emergence of new technology-based industries, and strong employment protection can substantially reduce the general attractiveness of these industries.

Second, labor adjustment costs weaken the specific business models of VC investors over-andabove market size effects. This can lower VC returns and lead them to decline otherwise fundable deals. Flexibility is central to the VC business model. Characteristic of entrepreneurial and innovative endeavors, most VC-backed companies fail despite the assistance. Successful investors maintain a portfolio of projects and reallocate resources aggressively from failing ventures to highperforming investments. ${ }^{9}$ This staged approach yields option values for investments, and VC investors close under-performing ventures for the sake of better opportunities. Strict employment protection increases the costs of these labor adjustments and closures, weakening the VC model. Despite these theoretical linkages, our empirical understanding of how labor regulations shape

\footnotetext{
${ }^{8}$ For example, Hopenhayn and Rogerson (1993), Saint-Paul (1997, 2002), Samaniego (2006), Bartelsman and Hinloopen (2006), Cuñat and Melitz (2010), Clark and Postel-Vinay (2009), and Algan and Cahuc (2009). This complements a larger literature on choices to be entrepreneurs like Khilstrom and Laffont (1979), Lazear (2005), Simons and Åstebro (2010), Parker and Van Praag (2011), and Chen (2012).

${ }^{9}$ Over half of $\mathrm{VC}$ investments yield zero or negative returns, with a small number of great successes generating most of the profits. For example, Sahlman (1990), Gompers and Lerner (2002), Kaplan and Strömberg (2003), Cochrane (2005), Gompers et al. (2009), Bengtsson (2011), and Da Rin et al. (2012). Puri and Zarutskie (2011) and Chemmanur et al. (2011) provide related evidence on the labor volatility of VC-backed firms in the US.
} 
VC investment is underdeveloped, especially at the sector level. ${ }^{10,11}$

\section{Empirical Approach}

Our analysis centers on differences across industries in their inherent labor volatilities. Measuring the inherent labor volatilities - as opposed to the realized labor volatilities by country and sector - is important given that labor market policies directly influence realized employment flows. Consider a sector with inherent labor volatility $v \geq 0$ in a country with employment protection levels $E P R \geq 0$. The sector is sufficiently small and open such that it takes prices and policies as exogenously determined.

A continuum of entrepreneurial opportunities in the sector of unit mass are ordered by their quality $q_{i}$, which is distributed uniformly from zero to $\bar{q}$. A risk neutral entrepreneur with a project quality $q_{i}$ decides to enter the market or not by examining the profitability $(1-t)\left[\pi\left(q_{i}\right)-c(v, E P R)\right]-F C$. In this expression, $t$ is the corporate tax rate, $\pi\left(q_{i}\right)$ is the natural profit for a given project quality, and $c(v, E P R)$ is an additional cost due to labor volatility and employment protection. $F C \geq 0$ is a fixed cost of entry that we assume cannot offset profits.

Profits are increasing in project quality: $\pi(0)=0$ and $\partial \pi / \partial q>0$ (e.g., $\pi=\gamma \cdot q, \gamma>0$ ). Higher volatility and employment protection generate higher costs: $c(0, E P R)=c(v, 0)=0$, $\partial c / \partial v>0, \partial c / \partial E P R>0$, and $\partial^{2} c / \partial v \partial E P R>0$ (e.g., $\left.c=\eta \cdot v \cdot E P R, \eta>0\right)$.

\footnotetext{
${ }^{10}$ Related empirical studies include Jeng and Wells (2000), Ilmakunnas and Kanniainen (2001), Parker and Robson (2004), Romain and van Pottelsberghe (2004), Kanniainen and Vesala (2005), Mayer et al. (2005), Da Rin et al. (2006), Armour and Cumming (2006), Micco and Pagés (2007), Cumming and Johan (2009), and Cuñat and Melitz (2010). Cumming (2013) strongly debates the Da Rin et al. (2006) methodology and results.

${ }^{11}$ As background for this project, we undertook semi-structured interviews of practitioners in ten European countries. Across respondent countries, investment managers generally believed labor regulations to be an important factor in local $\mathrm{VC}$ development, although several noted that they were willing to enter heavily regulated markets if other advantages existed like high quality labor. Two sample interview quotes are: "We want our early stage investments to grow quickly to 50-100 employees, but they may also need to fall back to 25 workers. Strict employment regulations make it less attractive for starting these risky businesses." Also, "National differences in labor regulations are an important factor for where pan-European funds place their resources."
} 
Entrepreneurs enter if their qualities equal or exceed a lower threshold $q_{\text {min }}$ defined by $(1-t)\left[\pi\left(q_{\min }\right)-c(v, E P R)\right]-F C=\bar{u}$, where $\bar{u}$ is a reservation utility, or $q \geq q_{\min }=$ $\pi^{-1}[(\bar{u}+F C) /(1-t)+c(v, E P R)]$. Thus, the size of the sector in terms of the number of firms can be represented as $\left(\bar{q}-q_{\text {min }}\right) / \bar{q}>0$. Sector size increases with a lower tax rate, lower employment protection, lower volatility, and lower fixed costs. Allow for two sectors that are identical, except sector 1 is more volatile than sector $2: v^{1}>v^{2}$. Sector 2 is larger than sector $1\left(q_{\min }^{1}>q_{\min }^{2}\right)$. Taking the simple case of a linear profit function $\pi=\gamma \cdot q$, differences in sector size grow with greater employment protection due to the incidence it has on labor adjustments, while changes in corporate taxes affect sectors equally due to their general incidence. ${ }^{12}$

This set-up is very simple but captures several key empirical issues. First, let the level of worker insurance provided in the country be $I(E P R, L M E)=\alpha_{E P R} E P R+\alpha_{L M E} L M E$, where $L M E \geq 0$ is labor market expenditures. This $I(\cdot)$ function assumes policies are additive and separable, and $\alpha_{E P R}, \alpha_{L M E}>0$ weight each policy's importance for worker insurance. Labor market expenditures are paid for by corporate taxes, such that $\partial t / \partial L M E>0$. If a policy maker seeks to maintain a level of insurance $\bar{I}$ but to move from a regime emphasizing employment protection to one emphasizing greater labor market expenditures, the required adjustment is $\Delta L M E=-\Delta E P R \cdot\left(\alpha_{E P R} / \alpha_{L M E}\right)$. Thus, higher corporate taxes are necessary to maintain a given insurance level as employment protection declines, and the relative size of the volatile sector to the less volatile sector increases in our simple linear case. ${ }^{13}$

\footnotetext{
${ }^{12}$ Technically, $\partial\left(q_{\min }^{1}-q_{\min }^{2}\right) / \partial E P R>0 ; \partial^{2} q_{\min } / \partial v \partial E P R>0 ; \partial\left(q_{\min }^{1}-q_{\min }^{2}\right) / \partial t=0 ; \partial^{2} q_{\min } / \partial v \partial t=0$. Adding curvature to the profit function yields sector growth differences with respect to marginal tax rate changes, but the spirit of our predictions with respect to labor volatility continues to hold.

${ }^{13}$ Technically, $\partial^{2} q_{\min } / \partial v \partial E P R>0, \partial q_{\min } / \partial v \partial t=0$. Whether or not sectors generally increase or decline requires further model structure $\left(\partial q_{\min } / \partial E P R>0, \partial q_{\min } / \partial t>0\right)$. The most likely scenario, and one for which we derive empirical support below, is that all sectors generally grow with the policy shifts away from employment protection. For simplicity, this framework does not model channels through which labor market insurance levels benefit sector size. Whether or not a higher overall level of labor market insurance improves
} 
Second, consider the empirical challenge of measuring sector volatility. Our starting assumption of constant volatility by sector does not hold under realistic scenarios where labor volatility varies across firms. Instead, a more appropriate metric is the inherent volatility of a sector across the full support $[0, \bar{q}] \cdot{ }^{14}$ Allowing volatility to vary continuously with quality $v(q)$, a natural assumption for our entrepreneurial setting is that higher quality opportunities have greater volatility as firms strive to obtain scale: $\partial v / \partial q>0$. In this case, $q_{\min }$ is implicitly defined by $(1-t)\left[\pi\left(q_{\min }\right)-c\left(v\left(q_{\min }\right), E P R\right)\right]-F C=\bar{u}$. Empirically, one would measure the average volatility of a given country and sector as $v o l=\left(\left(\bar{q}-q_{\min }\right) / \bar{q}\right)^{-1} \int_{q_{\min }}^{\bar{q}} v(i) d i$. As $q_{\min }$ is a function of EPR, measured volatility depends upon policy choices. Moreover, this selection margin worsens with stricter regulations and in more naturally volatile sectors, compounding concerns. ${ }^{15}$

Instead, the best setting to measure labor volatility and differences across sectors is where the distortions are weakest and the fullest distribution of entrants and firms is observed. Accordingly, our primary measures are developed using the volatilities of plants and firms in the US. US policies are the least distortionary, and we have a full census of firms spanning 1977-1999. In a hypothetical sector with no inherent labor volatility, we would not expect significant differences in $\mathrm{VC}$ formation across European countries due to their labor market policy choices. By contrast, US sectors with high labor volatility should exhibit substantive differences. ${ }^{16}$

or reduces investment levels differentially in volatile sectors is theoretically ambiguous. On one hand, generous insurance may reduce entrepreneurial incentives, potentially with industrial organization implications (e.g., the rapid mobility in the model of Fallick et al. 2006). Alternatively, a generous safety net may reduce worker insecurity and/or compensation differentials associated with job loss, effectively subsidizing volatile sectors.

${ }^{14}$ In practice, the lower bound of zero is unrealistic as it requires reservation utilities, fixed costs, and corporate taxes to all be zero, in addition to labor policies being non-distortionary. One might instead suggest the true measure to be $\left[q_{L B}, \bar{q}\right]$, where the lower bound $q_{L B}$ is defined by the lowest possible values of the above three factors.

${ }^{15}$ The general point is that observed labor volatilities for a country-sector are strongly influenced by selection margins and thus incomplete. These issues extend, albeit much more weakly, to differences in taxes, fixed costs, and reservation utilities. Related factors outside of our simple model are business model adjustments by firms and incomplete distributions of project ideas for small countries and sectors.

${ }^{16}$ The higher sensitivity of VC investors to labor policies can be easily incorporated by having these investors 


\section{Primary Data Sources and Variable Construction}

\section{Labor Market Insurance Policies}

We use this empirical framework to systematically link labor policies and VC investment levels across countries and industries in Europe. Tables 1A and 1B describe our 1990-2008 data. The start and end dates of our analysis are dictated by data availability constraints. Our VC data have sparse coverage prior to 1990, when European VC investments were very small. After 2008, we have substantial attrition in the availability of our labor market policy variables and related covariates. Moreover, adjustments in sector definitions by data providers make longer panels more difficult to construct. Our 19-year panel provides the best balance across these issues.

In Column 1 of Table 1A, the OECD employment protection index has a theoretical range from zero to five, with higher scores indicating more heavily regulated labor markets. The index factors in a wide variety of legislation concerning the individual and collective dismissals of both temporary and regular workers. The rating includes the difficulty of worker dismissals (e.g., to justify as "fair"), the required procedural steps, and mandated severance pay and notice periods. Its primary limitations are for capturing judicial procedures or voluntary contractual provisions. Table 1a gives the average value of this annual rating by country. Switzerland (1.1), Denmark (1.7), Portugal (3.7), and Spain (3.1) are extreme values within Continental Europe. The UK and Ireland sit between the US (0.2) and Continental Europe.

Labor market expenditures are also taken from the OECD. Unemployment insurance benefits are the majority of expenditures, with examples of other included active labor market programs

raise the volatility of their portfolio firms by a constant $\varepsilon>1$. As a benefit, $\mathrm{VC}$ investors can lower the fixed costs of entry, perhaps due to scarce industry expertise or financial constraints, or increase the profit function. In this framework, $\partial q_{\min }^{V C} / \partial E P R>\partial q_{\min } / \partial E P R$ and $\partial^{2} q_{\min }^{V C} / \partial v \partial E P R>\partial^{2} q_{\min } / \partial v \partial E P R$, where $q_{\min }^{V C}$ is the minimum VC threshold. 
being labor market training, school-to-work transition assistance for youth, and programs to help the unemployed obtain jobs. Denmark provides the highest average share from 1990-2008 at $4.8 \%$ (approximately 1482 ECUs/Euros per capita at sample mid-point), followed by Finland, Belgium, and Sweden. The UK provides the lowest expenditures at 0.9\% (173 ECUs/Euros per capita), followed by Italy, Switzerland, and Portugal. The $0.5 \%$ average for the US is again lower than any nation within Europe.

In addition to base policies, we also consider simple transformations to present these differences in the most intuitive manner. We first transform the base policies to have unit standard deviations so that their scales are comparable. We then measure the single-dimension distance for each policy from the lowest provision of that policy in the OECD. These distances have a maximum of less than four standard deviations. Our Levels Index is the average of these policy distances for each observation; it estimates in standard deviations the distance from a country's joint provision of (employment protection, labor market expenditures) to the OECD minimums. Column 3 and the vertical axis of Figure $1 \mathrm{~b}$ plot the average Levels Index by country across our time period. The UK and Switzerland provide the lowest insurance on average, while nine nations have average values above 3.4 .

Second, the Mechanism Index describes the technique used to provision labor market insurance. It is a radian measure of the labor market expenditures distance divided by the employment protection distance. The Mechanism Index can be thought of as the slope of a ray extending from the origin of Figure 1a to the nation's position in (employment protection, labor market expenditures) space. Larger values of the Mechanism Index indicate greater reliance on labor market expenditures. Portugal and Italy have the lowest average values, while Denmark and Ireland most emphasize labor market expenditures. These values are the horizontal axis of Figure 
1b, and the flat trend line for Continental Europe illustrates the policy substitution.

Table 1A provides the average values of the labor market policies, and Appendix Table 1 documents the full time series of our base policies and transformed insurance metrics. Across our time frame, most countries have constant employment protection or gradually move towards more flexibility. The simple average across countries declines from 2.6 in 1990-1994 to 2.1 in 2005-2008. The average labor market expenditure as a share of GDP also declines during our sample period, from 3.0 in 1990-1994 to 2.0 in 2005-2008. In terms of our transformed indices, the average Levels Index declines from 3.4 in 1990-1994 to 2.9 in 2005-2008. This average decline is due to weaker provision of both underlying policies. By contrast, the Mechanism Index does not show an average trend as both policies are declining together.

Our analysis exploits multiple tests of the link between labor policies and VC investment. Some frameworks utilize cross-sectional variation, while others utilize panel variation. To quantify the degree of variation exploited in each test, we conduct a within-between decomposition of variance. The within-country variations account for $13 \%$ and $20 \%$ of the total variations in our sample for employment protection and labor market expenditures, respectively; the betweencountry variation is the residual. Thus, countries' long-term positions represent a substantial share of the differences that exist. This stability in large part relates to the aggregate insurance levels countries select. With our index transformations, the within-country variations account for $43 \%$ and $15 \%$ of the total variations in our sample for the Mechanism Index and Levels Index, respectively. Thus, our transformations help isolate a more active policy dimension. We observe below that our key findings are evident using both within and between variation.

\section{VC Investment Data and Sector Volatility Measures}


Column 5 introduces simple counts of VC deals from Thomson's Venture Xpert database for 1990-2008. The Thomson data are the backbone of our primary estimations, and we discuss below European Private Equity and Venture Capital Association (EVCA) data used in robustness checks. Reassuringly, there is a close correspondence of aggregates between these two data sources. VC investment levels have been largest in absolute size in the UK, France, and Germany; relative to GDP, Finland, Ireland, Sweden, and Denmark stand out.

Column 1 of Table 1B considers the sector perspective using EVCA sectors ordered by investment levels. Computers and Communications are the largest. Appendix Table 2 provides more details on sector definitions. One important trait of the EVCA classification system is that the Computer and Communications categories focus on hardware and software development particular to those sectors. Thus, as an example, VC support for a start-up in on-line banking would fall under Financial services. Our empirical analysis considers cross-sectional and longitudinal variation in these placements. Appendix Table 3 shows that the sector distribution across countries is sufficient to support these exercises. ${ }^{17}$

Column 2 of Table 1B introduces measures of US labor volatility by sector. Our central metrics are calculated from the Longitudinal Business Database of the US Census Bureau over 1977-1999 at the establishment level. Over $80 \%$ of US establishments have 20 or fewer employees (Kerr and Nanda 2009). We calculate volatility across a long period to iso-

\footnotetext{
${ }^{17}$ Thomson's deal-level records allow us to separate VC activity from other private equity investment, which is unfortunately not possible at the sector level with the EVCA data. A second advantage of deal-level records is that we can consistently construct sectors over 1990-2008 by aggregating individual technologies, whereas EVCA sector definitions change in 2004. A liability of Thomson, however, is that investment amounts are not reported for about half of the deals. For this reason, we mostly focus on the count of deals by country-sector. When analyzing values we impute missing values by first regressing reported amounts on vectors of fixed effects for countries, sectors, years, and number of investors. We then predict deal values for missing observations using the estimated parameters subject to predicted values being above sector minimums. Thomson's coverage of deals increases during the sample period. Uniform changes by sector or country do not influence our results due to our fixed effect estimation approach, but coverage changes specific to a country-sector could bias our estimations. We have not identified such country-sector changes in collection procedures.
} 
late volatility estimates from particular business cycle conditions or industry life cycle stages. Following Davis et al. (1996), we calculate the employment volatility of establishment $e$ as $A B S_{e, t}=\left|E_{e, t}-E_{e, t-1}\right| /\left[\left(E_{e, t}+E_{e, t-1}\right) / 2\right]$. This formula divides the absolute change in employment by its average across the two years. This measure is bounded by $[0,2]$, prevents outliers, and symmetrically treats positive and negative shifts. This is important as labor adjustment costs can affect hiring decisions just as much as dismissals.

The establishment-level nature of this calculation is also important. First, from a theoretical perspective, micro-founded models of this type of phenomena like Samaniego (2006) embed this issue at the establishment or plant level (e.g., technological obsolescence of a facility), and many employment decisions are made within local units. Second, establishment-level employment fluctuations are more likely to resemble the typical experiences of VC firms. We also prefer establishment-level calculations to allow more accurate sector assignments and the entry and exit of plants that theoretical models emphasize (in addition to greater volatility). Nonetheless, we demonstrate below comparable results when calculating $A B S$ at the sector level.

After calculating $A B S$ at the establishment-year level, we take the mean across establishments within each sector across the full 1977-1999 period. We define sectors through two representative three-digit SIC industries where investments are likely to occur. Concordances are available from the authors upon request. We use this single time-invariant measure for each sector in our country-sector panel analysis. The Computer (0.52) and Energy (0.49) sectors have the greatest turnover, while Chemicals and materials (0.28) and Industrial products and services (0.31) have the lowest.

Table 2 provides simple tabulations to further describe our data and motivate our analysis of labor market policies. We start by grouping sectors into three bins according to their US 
labor volatility. Column 1 provides the average distribution of investments across the bins for Europe as a whole, and the notes to Table 2 list specific sectors by bin. In Columns 2-4, we use the Mechanism Index of labor market insurance to split countries into two groups based upon whether or not they tend to use employment protection more than labor market expenditures for providing a chosen level of insurance. Table 2's notes again list specific countries in each group. Column 4 compares the distributions, finding that countries favoring labor market expenditures over employment protection have a greater share of their investments in the high-volatility sectors and a reduced share in medium-volatility sectors. This pattern is not evident, by contrast, in Columns 5-7 where we split countries according to the Levels Index. This initial tabulation suggests policies are important, and our analysis below quantifies these differences in more rigorous estimation frameworks.

\section{Amadeus Database}

Our final data source is Bureau van Dijk's Amadeus database of several million public and private European companies. These company records constitute an unbalanced panel of operating entities. In addition to annual operating data like employment and sales, Amadeus contains information on firm ownership structures that includes whether or not a firm's owner is a private equity investor. We focus on Amadeus data during the 1999-2008 period when coverage is most complete. We combine Amadeus with Thomson's deal-level records using automated name-matching routines followed by manual verification and extensions. We first match portfolio companies in Thomson to operating firms in Amadeus, and we also match VC firms in Thomson to firm ownership structures. Over $70 \%$ of Amadeus' private equity owners are present in Thomson, and we use this match to isolate VC investors. The resulting dataset is a platform 
for examining VC selection and employment volatilities in the next section. We also estimate through Amadeus several country-sector traits described below that serve as controls. ${ }^{18}$

\section{Labor Volatility and Selection of VC-Backed Firms}

Table 3 quantifies the higher labor volatility of VC-backed firms in Europe compared to their peers through the matched Amadeus database. We measure labor volatility using the same $A B S$ formula that we use with the US data with two modifications: we are limited to firm-level fluctuations, rather than establishments, and we abstract from entry and exit since we do not observe the universe of firms. The mean values of $A B S$ within Amadeus are 0.232 for firms backed by VCs and 0.156 for firms generally. This difference is substantial, accounting for $42 \%$ of the interquartile range of employment volatility. The interquartile range of $A B S$ for VCbacked companies is also $37 \%$ larger than the interquartile range for the full sample, reflecting greater variability. For regressions, we transform $A B S$ to have unit standard deviation to aid interpretation. As the ownership data do not vary longitudinally for firms, we prepare a fixed indicator variable for VC ownership. The notes for each table provide additional details.

Column 1 simply regresses the $A B S$ metric on a constant and the VC indicator. The employment volatility of VC-backed firms is 0.29 standard deviations higher than typical firms. Columns 2 and 3 show that this difference is not due to VC-backed firms being in more volatile sectors or at a different point in their life cycle. The premium declines only slightly after controlling for country-industry-year fixed effects and the firm's contemporaneous employment and

\footnotetext{
${ }^{18}$ Data constraints on the ownership records limit Tables 3 and 4 to Amadeus records reported in the "medium and large" databases. Bureau van Dijk defines medium and large through the median firm size at the industry level across countries. This threshold value is quite small (median of one, mean of four workers). Results available from the authors demonstrate robustness to this selection in many ways. We confirm VC investment in $0.14 \%$ of the sample. This share may overstate true activity should Amadeus be more likely to include VC-backed companies. On the other hand, this share may understate activity as we are unable to determine type of private equity investor in many cases. Reported results consider cases where VC backing is confirmed, and additional analyses establish robustness to alternative approaches of assigning unidentified investors.
} 
revenues. Columns 4 and 5 show that the employment volatility premium persists after restricting the sample to country-industry pairs where $\mathrm{VC}$ investment is common (defined as more than $1 \%$ of firms). This bar excludes over $95 \%$ of the sample but further conforms treatment and control groups. Likewise, Column 6 finds a similar premium when taking a third approach of creating a control group that most closely matches the employment and revenues of the VCbacked firms within the same country-industry-year. VC-backed firms are systematically more volatile than their European peers.

Table 4 quantifies how selection and traits of VC-backed companies differ with employment protection and sector volatility. Coefficients come from a single regression of an indicator variable for VC backing on six traits of ventures - employment, revenues, assets per employee, firm age, wage, and EBITDA margins - and their interactions with US sector volatility, employment protection in the country, and their joint interaction. The first row shows that VC-backed ventures tend to be larger in terms of employment, more capital intensive, younger, and employ higher-wage workers than other firms in the country-industry-year. Conditional on other traits, VC-backed ventures also have lower revenues and earnings. These patterns are modestly accentuated in high volatility sectors. The third and fourth rows consider employment protection levels and their interactions with sector volatility. Stronger employment protection is associated with a partial diminishing of traits typically associated with VC investment. This pattern, moreover, is especially pronounced in volatile sectors where investments shift towards smaller and older businesses that have more revenues and better EBITDA margins. Stricter labor regulations appear associated with safer investments, especially in high volatility sectors. ${ }^{19}$

\footnotetext{
${ }^{19}$ As noted in the prior section, we match the Thomson and Amadeus databases at both the operating company and firm owner levels. The reported specifications are conservative in that we only include exactly matched cases on both dimensions. Given the very large size of the non-VC-backed sample, we obtain very similar results with
} 


\section{VC Placements in Europe}

\section{Primary Specifications}

Tables 5-7 quantify the country-sector formation of VC investments. We consider both crosssectional dimensions and longitudinal changes across four periods: 1990-1994, 1995-1999, 20002004, and 2005-2008. We have 840 observations from 15 countries, 14 sectors, and four periods. Even with five-year periods, some country-sector-period observations have no investments. We thus first consider the extensive margin through a $(0,1)$ indicator variable for one or more VC investments on average per year in the country-sector-period. We then consider the intensive margin through log investment counts and amounts. The latter specifications include 671 observations with positive investment levels.

Table 5 provides cross-sectional estimations similar to Rajan and Zingales (1998), Carlin and Mayer (2003), and Klapper et al. (2006). These estimations take the form,

$$
V C_{c, s, t}=\phi_{c, t}+\eta_{s, t}+\beta_{E P R} E P R_{c, t} \cdot L a b o r V o l_{s}^{U S}+\beta_{L M E} L M E_{c, t} \cdot \text { LaborVol }_{s}^{U S}+\varepsilon_{c, s, t},
$$

where $c$ indexes countries and $s$ indexes sectors. The first explanatory variable in Columns 1-3 of Panel A is the country's OECD employment protection index interacted with time-invariant US sector volatility. The second is a similar interaction of US sector volatility with labor market expenditures as a share of GDP. These specifications include sector-period fixed effects (FEs) $\eta_{s, t}$ and country-period FEs $\phi_{c, t}$ that account for aggregate growth in sector and country VC investment over time. These FEs also absorb the main effects of the labor policies and sector volatilities. Identification comes from cross-sectional variation in sector size across countries,

other strategies like retaining all partial or suspected matches. 
testing the prediction that stricter labor policies should particularly hinder development of VC investments in more volatile sectors.

The first row finds broad evidence that higher employment protection is associated with lower $\mathrm{VC}$ investment in volatile sectors, while the second row shows the opposite pattern with labor market expenditures. Our model describes how policy adjustments along a given insurance frontier require changes of $\triangle L M E=-\Delta E P R \cdot\left(\alpha_{E P R} / \alpha_{L M E}\right)$ to maintain a fixed insurance level. Using our regression results, the impact of such an adjustment on $\mathrm{VC}$ investment is $\Delta V C=\beta_{L M E} \Delta L M E+\beta_{E P R} \Delta E P R=\beta_{L M E}-\beta_{E P R} \cdot\left(\alpha_{L M E} / \alpha_{E P R}\right)$. The last row of Panel A presents this comparative static with $I(\cdot)$ defined by $\alpha_{L M E}=\alpha_{E P R}$. This equal contribution of employment protection and labor market expenditures is motivated by Figure 1a's policy trade-off within Continental Europe. The linear combinations of $\beta_{L M E}-\beta_{E P R}$ are more stable and well-measured than the individual policies are.

Panel B instead considers as explanatory variables the interactions of the Levels and Mechanism Indices with US labor volatilities by sector. These estimations highlight the importance of the mechanisms used to provision insurance, with a shift towards more flexible policies associated with stronger VC development in volatile sectors. The stability of the Mechanism Index interaction mirrors that of the linear policy combination at the bottom of Panel A.

Columns 4-6 include controls of country-sector employment levels and mean wages, countrysector-period patenting, lagged share of past country-sector-period VC investments achieving initial public offerings, and share of $\mathrm{VC}$ investments by country-sector-period in seed and early stages. Unmodeled factors that vary by country-period or sector-period are captured by the FEs. These controls proxy imperfectly for potentially confounding aspects by country-sector like differences in life cycles, technology opportunities, past investor returns, and similar factors 
that influence demand for VC. As many of these outcomes can be endogenous to the link between labor policies and VC investment, showing stability with and without the controls is important. ${ }^{20}$

Section 2 described how labor market policies can have both market size effects that encourage or deter VC investments, with VC remaining a constant share of the country-sector activity, and business-model effects that deter VC investments in particular. We can make a rough estimate of these features by excluding our market size control. Doing so, we estimate coefficients for the Mechanism Index of 0.030 (0.008) and 0.107 (0.042) in the entry and log count regressions, respectively. Comparing these coefficients to those in Table 5 suggests that market size effects are about $7 \%$ of the total on the entry margin, and they are about $23 \%$ on the intensive margin. Because we are not able to consistently measure the general size of country-sectors across the whole sample period, we cannot distinguish these features in the upcoming longitudinal analyses. Thus, these panel estimates combine the two effects.

Table 6 provides longitudinal estimations that include country-sector FEs $\mu_{c, s}$ and sectorperiod FEs $\eta_{s, t}$. These estimations take the form,

$$
\begin{aligned}
V C_{c, s, t}= & \mu_{c, s}+\eta_{s, t}+\gamma_{E P R} E P R_{c, t}+\beta_{E P R} E P R_{c, t} \cdot \text { LaborVol }_{s}^{U S} \\
& +\gamma_{L M E} L M E_{c, t}+\beta_{L M E} L M E_{c, t} \cdot \text { LaborVol }{ }_{s}^{U S}+\varepsilon_{c, s, t} .
\end{aligned}
$$

\footnotetext{
${ }^{20}$ We measure employment and wages from Amadeus; patenting from the European Patent Office (EPO) and US Patent and Trademark Office (USPTO) datasets; IPO activity for our Thomson sample from Capital IQ, SDC, and manual searches; and seed and early stage VC shares from Thomson. The EPO and USPTO datasets have their own technology classifications that we map to EVCA sectors.

In our data, wages are negatively correlated with employment protection levels. In the standard competitive model of the labor market, employment protections are economically equivalent to mandated employment benefits. Benefit mandates raise the cost of employing workers, leading to a decline in labor demand by firms for a given wage rate. To the extent that workers value the mandate, they will increase their labor supply at a given wage. If workers value the mandated benefit at its marginal cost of provision, then equilibrium employment levels are unchanged and wages fall to cover exactly the cost of the benefit. In this scenario, the mandate is efficient and the Coase theorem applies (e.g., Summers 1989, Lazear 1990). Autor et al. (2007) review wage adjustments in scenarios when the mandate is not efficient.
} 
Country-sector FEs remove cross-sectional differences across country-sectors in labor policies, VC investment levels, and similar. Sector-period FEs control for overall European VC growth by sector. As we do not model country-period FEs, we estimate the main effects of the two labor policies $\left(\gamma_{E P R}, \gamma_{L M E}\right)$ in addition to their interactions. Main effects capture longitudinal responses that are common to all sectors within a country; the interactions capture the differential in longitudinal response across sectors due to their labor volatility. We include a log GDP control in these estimations, and Columns 4-6 again consider additional controls.

Panel A shows that the main effects of the two policies and their volatility interactions are in the predicted direction, although some coefficients are not precisely measured. The linear combination of effects at the bottom of Panel A finds strong effects for the comparative static of reducing employment protection while increasing labor market expenditures. Panel B shows this even more cleanly when using the Levels and Mechanism Indices and their interactions. The main effects for the Mechanism Index suggest that shifts in policies towards more flexible markets are associated with an increase in VC entry and investment counts across all sectors. The interaction effect further suggests that this increase is particularly strong in more volatile sectors. By contrast, there are no clear findings for the Levels Index.

Table 7 adds country-period FEs $\phi_{c, t}$ to the longitudinal specification in a triple-difference. These estimations take the form,

$$
V C_{c, s, t}=\mu_{c, s}+\phi_{c, t}+\eta_{s, t}+\beta_{E P R} E P R_{c, t} \cdot \text { LaborVol }_{s}^{U S}+\beta_{L M E} L M E_{c, t} \cdot \text { LaborVol }_{s}^{U S}+\varepsilon_{c, s, t} .
$$

The specification requires that within-country shifts in worker insurance policies towards more flexible techniques connect with increases in $\mathrm{VC}$ financing (the first differencing due to the 
country-sector FEs $\mu_{c, s}$, a longitudinal response) that exceed the overall sector growth for Europe (the second differencing due to sector-period FEs $\eta_{s, t}$ ) and that are strongest in sectors with greater intrinsic labor volatility (the third differencing due to country-period FEs $\phi_{c, t}$ ). As a consequence, we no longer estimate main effects. The interaction patterns persist: VC growth is particularly strong in volatile sectors when countries are shifting towards more flexible labor policies. It is very important for these results to recall that sector volatility is time-invariant and measured using US data, so that changes are only being identified through policies. ${ }^{21}$

\section{Robustness Checks}

Tables 8 and 9 report robustness checks on the entry and count specifications using Table 6's longitudinal specification that allows main effects and interactions. ${ }^{22}$ Across the many robustness checks considered, we select these to highlight strengths and limitations to our results. Column 1 of Table 8 finds comparable results using US sector-level volatility from 1992-1999. In general, our results are quite robust to different volatility metrics and to including additional interactions of sector growth rates and labor policies, indicating higher volatility is not proxying for growth.

Our main regressions are weighted by an interaction of aggregate country size with aggregate sector size. We place more faith in weighted estimations than unweighted estimations since many country-sector observations are by their nature very small (e.g., Austria's energy sector). Measurement error is generally less for larger countries and sectors. However, we avoid weighting

\footnotetext{
${ }^{21}$ We do not emphasize log investment values due to data construction issues and imputed values. If we exclude observations with missing deal values, our sample diminishes to 581 country-sector-period observations. This smaller sample yields directionally similar results that are statistically significant when using base policies and insignificant when using transformed policies. For example, the cross-sectional coefficients akin to Column 3's Panel B of Table 5 are $0.095(0.082)$ and -0.035 (0.065). The triple-difference results similar to Column 3's Panel B of Table 7 are $0.097(0.079)$ and -0.090 (0.249).

${ }^{22}$ We focus on Table 6's specification as it conveys the most information since it retains the main policies. The interaction effects documented in these robustness checks are quite similar if instead using Table 7's tripledifferenced framework.
} 
by realized country-sector size since this is endogenous to the studied mechanisms. The interaction focuses attention on better measured outcomes without encountering this latter concern. Column 2 excludes sample weights and finds qualitatively similar results. Coefficient patterns are very similar. The main effect for the Mechanism Index is statistically significant in the entry estimation, while the interaction effect is statistically significant in the count regression.

Columns 3 and 4 test excluding certain economies or sectors. The most sensitive part of our estimations is the inclusion of the Anglo-Saxon economies, shown in Column 3. The entry margin remains secure overall: the main effect becomes more powerful, while the interaction effect grows slightly in economic magnitude but becomes imprecisely estimated due to the reduced variation. For the count specification in Panel B, the main effect again remains of similar magnitude but loses its statistical significance. The more disappointing aspect is that the interaction effect in Panel B loses all power. We further comment on this Anglo-Saxon sensitivity below in the Discussion section. By contrast, Column 4 shows very similar results when excluding the computer sector. In general, the results are quite robust to sector adjustments or to country adjustments beyond the highlighted Anglo-Saxon sensitivity.

Column 5 considers EVCA data that combine VC and buy-out placement. The sample covers 1990-2007 but is smaller than our main sample as the EVCA sector changes implemented in 2004 restrict us to nine sectors. We find support for our main effect in the EVCA data but not for the interaction effect. Similar to the analysis that drops the Anglo-Saxon economies, the two data sources show strong similarity in the cross-section placements at the country and sector levels, and they have comparable main effects in panel estimations. Differences emerge when looking at longitudinal changes at the country-sector interaction (the triple difference). ${ }^{23}$

\footnotetext{
${ }^{23} \mathrm{An}$ initial investigation of buy-out investors is available upon request. Portfolio companies tend to be in
} 
Column 6 considers modifications to our index design. Our goal is to provide joint policy tests that are easy to implement with readily available data so that they are useful to practitioners. The linear difference reported in Panel A of Tables 5-7 is important in this context, as it is straightforward to recalculate $\beta_{L M E}-\beta_{E P R} \cdot\left(\alpha_{L M E} / \alpha_{E P R}\right)$ with other policy weights $\alpha_{L M E}, \alpha_{E P R}$. Our Mechanism and Levels Indices are also intended to be simple. One technical issue with our approach is that we transform the two base policies to have unit standard deviation before combining. Transformations of categorical variables like the employment protection index can be problematic due to scale definitions. While acknowledging this issue, we are comfortable with our approach as the OECD index is granular (e.g., it has values similar to "2.12" on its five-point scale that are well distributed with a density maximum of $6.7 \%$ of any single value). Column 6 shows similar results without the standard deviation transformation in the index design (coefficient magnitudes are not directly comparable)

We obtain very similar results when normalizing labor market expenditures by country population instead of GDP. This comparability suggests that country wealth or wages levels are not determining the patterns observed. We likewise obtain very similar results when normalizing labor market expenditures by country unemployment levels. This stability further confirms that our results are not being driven by cyclical features of automatic stabilizers like unemployment insurance benefits. We likewise find close results with many other construction details. ${ }^{24}$

less-volatile industries but to be more volatile than their peers. A correlation exists between cross-sectional placements and labor policies, but we do not discern a longitudinal link similar to that evident for VC investors.

${ }^{24}$ We also find similar outcomes when replacing the Mechanism Index, which employs a bounded radian measure of policy ratios, with a simple ratio of policy distances. The radian measure is a simple monotonic transformation (inverse tangent) of the base distance ratio that is bounded by $[0, \pi / 2]$ and eliminates asymmetry. Likewise, we find similar results when estimating the overall labor market insurance level through Euclidean distances rather than linear distances. A second variant uses empirical results from Clark and Postel-Vinay (2009) to weight the Levels Index by how much employment protection and labor market expenditures boost workers' perceptions of security. The greater importance of policy mechanisms persists with these index variants. 
European countries trade extensively, and labor market insurance policies can create Ricardian comparative advantages. Indeed, theory models often use this construct for identifying why labor policies should matter for industry differences across countries. Ricardian trade theory in a multi-country setting replicates the cross-sectional predictions of our simple model, but localized comparative statics are not generally defined (e.g., Costinot et al. 2011). Related to this, despite the longitudinal changes we exploit, the rank orders of countries in terms of policies are very persistent. In such settings, interaction effects may not capture well the localized shifts in sector specialization. To confirm that our results are robust to estimation choice, we also analyzed the aggregate volatility embodied in $\mathrm{VC}$ investments by country-period weighting across sectors. This approach mirrors our panel estimation results.

Beyond these tests of estimation design, Table 9 considers a second set of robustness checks where we consider other policies beyond labor market insurance mechanisms. We have deemphasized these alternative factors until now because we instead sought to design the empirical framework in such a way as to naturally focus on labor issues only (e.g., the interactions with volatility indices). In Table 9, we consider several policy alternatives, in each case entering the base metric in the regression and an interaction of it with labor volatility. Columns 1 and 2 consider public R\&D investments as a share of GDP and the country's corporate tax rate (e.g., Keuschnigg and Nielsen 2003). Public R\&D investments are associated with higher VC investments, with extra tilt towards more volatile sectors, while a systematic relationship with corporate tax rates is not evident. These controls do not materially influence our results.

Armour and Cumming $(2006,2008)$ and Cumming (2012) identify the importance of bankruptcy law to entrepreneurship. Bankruptcy law and employment protections both have consequences for the speed and form that entrepreneurial adjustments can take and, in that sense, 
are quite related. Bankruptcy law strongly governs how quickly entrepreneurs can move from a failed idea to a new venture. Employment law shapes how quickly entrepreneurs can adjust firm size in response to changes in market conditions, technological updates, and similar news. These policies are connected since once the appropriate employment adjustment is to close the firm, bankruptcy provisions become central if the business is insolvent. Fear of bankruptcy may also impact the types of businesses pursued and risks undertaken, similar to how potential employment regulation costs shape the actions and choices of firms.

Using metrics from Cumming (2012), we consider in Columns 3 and 4 the importance of bankruptcy provisions and minimum capital requirements for firms. These measures are not available for all of the countries in our sample, and so the sample size declines somewhat. In our data, bankruptcy provisions are very important, regardless of which metric from Cumming (2012) we take, with more stringent bankruptcy laws reducing entrepreneurship with a magnitude comparable to the main effect that we estimate for the Mechanism Index. We do not observe, however, a systematic link to sector volatility. Inclusion of these controls does not influence our coefficient estimates much.

Column 5 considers public venturing's role (e.g., Leleux and Surlemont 2003). Our EVCA data separate at the country level investments that are made by public sources versus private investors. We introduce in Column 5 a control for the share of total private equity funds in the country coming from public sources along with its interaction with the volatility index. This does not influence our results, and we also find similar robustness to alternative techniques like entering public sector investments per capita. Our results are also robust to controlling for total government expenditures per capita, the level of captive investments for private equity, and aggregate private equity growth rates by sector. 
Column 6 considers a broader control based upon the legal origins of countries (e.g., La Porta et al. 1997). Legal origins have been shown to influence many policy choices that countries make, including labor laws, and so we include in our regressions a linear time trend interacted with indicator variables for the four main legal origin groups. The results are very similar with this control. If including origin-year fixed effects, our results look quite similar to those in Table 7 that include country-year fixed effects. That is, we no longer estimate a strong main effect, but we find the differences across sectors to be quite strong.

Beyond these robustness checks, we conducted additional analyses at the cross-sectional level in cases where we could not construct a longitudinal control. These include the strength of stock markets, business entry regulation barriers, product market regulations, collective bargaining arrangements or trade union density, government ownership of banks, the concentration of the banking sector, and similar. These tests, along with the tight link of our labor policies to the labor volatilities of sectors, provide a measure of assurance that our work is not simply picking up unmodeled policy factors.

Finally, we close this empirical section with estimates in Table 10 of the relative magnitudes of the main effects for policies. This paper generally seeks to establish and characterize the role of labor market policies using econometric techniques like the differenced Rajan and Zingales (1998) methodology. This technique helps isolate the role of labor market policies from other country traits and policies. This technique, however, does not provide estimates of the relative importance of labor policies compared to other factors. Nor does its sector-level characterization easily extend to such cross-policy comparisons without developing extensive additional traits of other sectors (e.g., the inherent likelihood of a company going bankrupt or paying corporate taxes). 
To provide a sense of these relative policy magnitudes, we consider in Table 10 a joint estimation of the main effects developed in Table 9's robustness analysis. This panel estimation continues to include country-sector and sector-period fixed effects. Explanatory variables are transformed to have unit standard deviation to facilitate comparison. We also report the estimates for the controls variables that have been included throughout this study. Column 1 considers the extensive margin of entry of VC investment, while Column 2 considers the log count of investments.

The table provides several basic themes about the comparative sizes of these effects. First, the bottom of the table shows that country GDP is easily the strongest predictor of investments, often an order of magnitude greater than the policy choices. This is not surprising and provides a good baseline for comparison. Second, in accordance with the earlier results, shifts in the Mechanism Index towards more flexible policies are associated with higher investment levels with elasticities around 0.15. In the presence of these covariates, the Levels Index is associated with a stronger reduction in investments with elasticities of $0.25-0.35$. This latter result suggests declines in worker insurance boost investment levels, although we continue to view the Mechanism Index as the more policy relevant parameter.

In terms of magnitudes, these labor policies have predictive strength comparable to or greater than the other policies modeled on the extensive margin. The most consistent detractor from investment levels is stringent bankruptcy provisions, with a magnitude two-thirds of the size of the Mechanism Index. Increases in corporate tax rates correlate with higher investments. On the intensive margin, the labor policy magnitudes are quite comparable to the other policies and public venturing. These results suggest that labor policies play an important role worthy of careful policy attention, and that their connection to investment levels is on par with bankruptcy 
provisions, for example, or the boost associated with past IPO success for ventures in a countrysector. It is important to emphasize that this comparability is calculated holding fixed the overall level of worker insurance provided - it comes solely through careful policy design, and countries willing to adjust overall worker insurance levels may harness additional gains. This comparability is also robust to including time trends for the legal origins of countries, considering log investment amounts, and similar variants.

\section{Discussion}

Looking across Tables 5-10, we conclude that labor market insurance policies have an important link to the formation of VC investment. We acknowledge, however, that this analysis has limitations, and we discuss here four important ones. First, despite Table 9 and related tests, omitted factors may bias our estimates. In our defense, our results are strongly bolstered by evidence of the same pattern with techniques ranging from cross-sectional work like Figure 1 and Table 2 to estimates that employ the triple-difference strategy of Table 7. Alternative factors would also have to operate at the country-sector level, have a tight link to sector volatility, and be able to replicate these multiple levels of outcomes. We have yet to identify such a factor that our results are not robust to, but one may exist that we have not identified.

Related, we remain cautious about reverse causality as we do not have exogenous policy shocks. So, it is possible that the disproportionate development of $\mathrm{VC}$ in volatile sectors for a country prompts the adjustment of labor policies to accommodate these investors. This does not seem likely given the broader political economy of employment protection laws, especially given the smaller sizes of the most impacted sectors. But, this response might be possible given policy makers' desire to promote VC investment. On the other hand, one could view the entry 
and development of European VC from 1990 onwards as a large location choice exercise. From this perspective, one can predict remarkably well the sector-level sorting that will occur from initial labor market policies that existed well before encouraging VC became an objective.

Beyond these first two issues, we earlier noted that our results are sensitive to the inclusion of the Anglo-Saxon economies, and it is useful to summarize what we observe. First, this paper has sought to establish the labor market linkage to VC investments at many levels, from cross-sectional analyses to triple-differenced approaches. Cross-sectional analyses, like the Rajan and Zingales (1998) methodology, and panel estimations of main effects are generally robust to whether or not the Anglo-Saxon economies are included. In most cases, coefficient estimates are of similar economic magnitude when excluding the Anglo-Saxon economies, with some decline in statistical precision from the reduced sample size and variation. However, one would rarely, if ever, reject the hypothesis that the coefficients are equal to those in the full sample, and the conclusions from these analyses would be the same. On the other hand, the key limitation is that noted in Table 8. Our triple-differenced results on the intensive margin of investment counts depend upon including the Anglo-Saxon economies. This is disappointing as the tripledifferenced variation is the most secure from alternative explanations. It is worth noting that this sensitivity is not because the Anglo-Saxon economies are on a different long-run trend from the rest of the sample, as we find very strong results when including time trends for the legal origins of countries in Table 9 (which effectively adds a time trend for Anglo-Saxon economies). Instead, triple-differencing requires a lot of variation to be successful, and excluding the AngloSaxon economies substantially lowers the variation we can exploit. We flag this issue for future researchers to evaluate in their own studies.

Finally, our VC investments results should not be used to argue that innovation itself must 
rise. Unreported estimations examine patent counts as the dependent variable. The estimations find a positive and significant longitudinal correlation of the Mechanism Index for patents at the country level, but not the sector-level differentiation that we emphasize. This limited response may question the causal link of VC to innovation (e.g., Ueda and Hirukawa 2008a,b) or may indicate substitution by private or public entities. Given differences in Europe's innovation structure (e.g., Belenzon and Berkovitz 2010), this is particularly important for future research.

\section{Conclusions}

While many European business leaders and policy makers seek to foster VC investments into their economies, the most productive path towards this goal remains uncertain. This paper quantifies a key determinant of these patterns in labor market policies that are discussed less frequently than R\&D subsidies or public venturing. European economies empirically substitute between employment protection and labor market expenditures to provide worker security. Employment protection more directly taxes labor force adjustments, and VC investors are especially sensitive to this choice given the sectors in which they operate and their business models. This factor can explain some of the substantial heterogeneity across Europe in the volume, traits, and importance of $\mathrm{VC}$ investments. Continued integration of Europe, encouraging ever stronger cross-border investment flows and location choice options, may further accentuate these effects.

\section{References}

Addison, J., and P. Teixeira (2003), "The Economics of Employment Protection", Journal of Labor Research 24:1, 85-129.

Alcacer, J., and W. Chung (2007), "Location Strategies and Knowledge Spillovers", Management Science 53:5, 760-776.

Alesina, A., E. Glaeser, and B. Sacerdote (2001), "Why Doesn't the United States Have a European-Style Welfare State?", Brookings Papers on Economic Activity 2001:2, 187-277.

Algan, Y., and P. Cahuc (2009), "Civic Virtue and Labor Market Institutions", American Economic Journal: Macroeconomics 1:1, 111-145. 
Ardagna, S., and A. Lusardi (2009), "Where Does Regulation Hurt? Evidence From New Businesses Across Countries", Harvard University Working Paper.

Armour, J., and D. Cumming (2006), "The Legislative Road to Silicon Valley", Oxford Economic Papers 58, 596-635.

Armour, J., and D. Cumming (2008), "Bankruptcy Law and Entrepreneurship", American Law and Economics Review 10, 303-350.

Åstebro, T., J. Chen, and P. Thompson (2011), "Stars and Misfits: Self-Employment and Labor Market Frictions", Management Science 57, 1999-2017.

Autor, D., W. Kerr, and A. Kugler (2007), "Does Employment Protection Reduce Productivity? Evidence from U.S. States", Economic Journal 117:521, 189-217.

Bartelsman, E., and J. Hinloopen (2006), "Unleashing Animal Spirits: Investment in ICT and Economic Growth", in Soete, L., and B. ter Weel (eds.), The Economics of the Digital Society, Edward Elgar, 272-304.

Belenzon, S., and T. Berkovitz (2010), "Innovation in Business Groups", Management Science $56: 3,519-535$.

Bengtsson, O. (2011), "Covenants in Venture Capital Contracts", Management Science 57:11, 1926-1943.

Blanchard, O., and P. Portugal (2001), "What Hides Behind an Unemployment Rate: Comparing Portuguese and U.S. Labor Markets", American Economic Review 91:1, 187-207.

Blanchard, O., and J. Tirole (2007), "The Optimal Design of Unemployment Insurance and Employment Protection: A First Pass", Journal of European Economic Association 6:1, 45-77.

Blanchard, O., and J. Wolfers (2000), "The Role of Shocks and Institutions in the Rise of European Unemployment: The Aggregate Evidence", Economic Journal 100, C1-C33.

Boeri, T., V. Galasso, and J.I. Conde-Ruiz (2010), "The Political Economy of Flexicurity", Journal of European Economic Association, forthcoming.

Brügemann, B. (2007), "Employment Protection: Tough to Scrap or Tough to Get?", Economic Journal 117:521, 386-415.

Cabral, L., and J. Mata (2004), "On the Evolution of the Firm Size Distribution: Facts and Theory", American Economic Review 93, 1075-1090.

Carlin, W., and C. Mayer (2003), "Finance, Investment, and Growth", Journal of Financial Economics 69:1, 191-226.

Chemmanur, T., K. Krishnan, and D. Nandy (2011), "How Does Venture Capital Financing Improve Efficiency in Private Firms? A Look Beneath the Surface", Review of Financial Studies 24:12, 4037-4090.

Chen, J. (2012), "Selection and Serial Entrepreneurs", Journal of Economics and Management Strategy, forthcoming.

Clark, A., and F. Postel-Vinay (2009), "Job Security and Job Protection", Oxford Economic Papers 61:2, 207-239.

Cochrane, J. (2005), "The Risk and Return of Venture Capital", Journal of Financial Economics 75, 3-52.

Costinot, A., D. Donaldson, and I. Komunjer (2011), "What Goods Do Countries Trade? A Quantitative Exploration of Ricardo's Ideas", Review of Economic Studies, forthcoming.

Cumming, D. (2012), "Measuring the Effect of Bankruptcy Laws on Entrepreneurship Across Countries", Journal of Entrepreneurial Finance, forthcoming 
Cumming, D. (2013), "Public Economics Gone Wild: Lessons from Venture Capital", Working Paper.

Cumming, D., and S. Johan (2009), Venture Capital and Private Equity Contracting: An International Perspective, Elsevier Science Academic Press.

Cuñat, A., and M. Melitz (2010), "Volatility, Labor Market Flexibility and Comparative Advantage", Journal of the European Economic Association, forthcoming.

Da Rin, M., G. Nicodano, and A. Sembenelli (2006), "Public Policy and the Creation of Active Venture Capital Markets", Journal of Public Economics 90, 1699-1723.

Da Rin, M., M. Puri, and T. Hellmann (2012), "A Survey of Venture Capital Research", in G. Constantinides, M. Harris, and R. Stulz (eds.) Handbook of the Economics of Finance Volume 2, North Holland, Amsterdam.

Davis, S., J. Haltiwanger, and S. Schuh (1996), Job Creation and Destruction, MIT Press, Cambridge, MA.

Delgado, M., M. Porter, and S. Stern, (2010a), "Clusters and Entrepreneurship", Journal of Economic Geography 10:4, 495-518.

Delgado, M., M. Porter, and S. Stern, (2010b), "Clusters, Convergence and Economic Performance", CES Working Paper 10-34.

EVCA Yearbook (2005), "Annual Survey of Pan-European Private Equity and Venture Capital Activity", EVCA, Brussels, Belgium.

Fallick, B., C. Fleischman, and J. Rebitzer (2006), "Job-Hopping in Silicon Valley: Some Evidence Concerning the Microfoundations of a High-Technology Cluster", Review of Economics and Statistics 88:3, 472-481.

Franco, A., and M. Mitchell (2008), "Covenants not to Compete, Labor Mobility, and Industry Dynamics", Journal of Economics and Management Strategy 17:3, 581-606.

Gilson, R. (1999), "The Legal Infrastructure of High-Technology Industrial Districts: Silicon Valley and Covenants Not to Compete", New York University Law Review. See also 1997 Stanford Law School Working Paper.

Glaeser, E., S. Kerr, and W. Kerr (2012), "Entrepreneurship and Urban Growth: An Empirical Assessment with Historical Mines", NBER Working Paper 18333.

Glaeser, E., and W. Kerr (2009), "Local Industrial Conditions and Entrepreneurship: How Much of the Spatial Distribution Can We Explain?", Journal of Economics and Management Strategy $18: 3,623-663$.

Gompers, P., A. Kovner, and J. Lerner (2009), "Specialization and Success: Evidence from Venture Capital", Journal of Economics and Management Strategy 18:3, 817-844.

Gompers, P., and J. Lerner (2002), The Venture Capital Cycle, MIT Press, Cambridge, MA.

Hopenhayn, H., and R. Rogerson (1993), "Job Turnover and Policy Evaluation: A General Equilibrium Analysis", Journal of Political Economy 101:5, 915-938.

Hsu, D. (2004), "What Do Entrepreneurs Pay for Venture Capital Affiliation?", Journal of Finance 59, 1805-1844.

Hyde, A. (2003), Working in Silicon Valley: Economic and Legal Analysis of a High-Velocity Labor Market, M.E. Sharpe, 91-141. See also 1998 Rutgers Law School Working Paper.

Ilmakunnas, P., and V. Kanniainen (2001), "Entrepreneurship, Economic Risks, and Risk Insurance in the Welfare State: Results with OECD Data 1978-93", German Economic Review 2, 195-218. 
Jeng, L., and P. Wells (2000), "The Determinants of Venture Capital Funding: Evidence across Countries", Journal of Corporate Finance 6, 241-289.

Kanniainen, V., and T. Vesala (2005), "Entrepreneurship and Labor Market Institutions", Economic Modelling 22, 828-884.

Kaplan, S., and P. Strömberg (2003), "Financial Contracting Theory Meets the Real World: An Empirical Analysis of Venture Capital", Review of Economic Studies 70:2, 281-315.

Kerr, W. (2011), "Income Inequality and Social Preferences for Redistribution and Compensation Differentials", NBER Working Paper 17701.

Kerr, W., J. Lerner, and A. Schoar (2012), "The Consequences of Entrepreneurial Finance: Evidence from Angel Financings", Review of Financial Studies, forthcoming.

Kerr, W., and R. Nanda (2009), "Democratizing Entry: Banking Deregulations, Financing Constraints, and Entrepreneurship", Journal of Financial Economics 94, 124-149.

Keuschnigg, C. and S. Nielsen (2003), "Tax Policy, Venture Capital, and Entrepreneurship", Journal of Public Economics 87:1, 175-203.

Khilstrom, R., and J.-J. Laffont (1979), "A General Equilibrium Entrepreneurial Theory of Firm Formation Based on Risk Aversion", Journal of Political Economy 87, 719-748.

Klapper, L., L. Laeven, and R. Rajan (2006), "Entry Regulation as a Barrier to Entrepreneurship", Journal of Financial Economics 82, 591-625.

Kortum, S., and J. Lerner (2000), "Assessing the Contribution of Venture Capital to Innovation", RAND Journal of Economics 31:4, 674-692.

La Porta, R., F. Lopez-de-Silanes, A. Shleifer, and R. Vishny (1997), "Legal Determinants of External Finance", Journal of Finance 52:3, 1131-1150.

Lafontaine, F., and J. Sivadasan (2009), "Do Labor Market Rigidities have Microeconomic Effects? Evidence from Within the Firm", American Economic Journal: Applied Economics $1: 2,88-127$.

Lazear, E. (1990), "Job Security Provisions and Employment", Quarterly Journal of Economics 105:3, 699-726.

Lazear, E. (2005), "Entrepreneurship", Journal of Labor Economics 23, 649-680.

Leleux, B., and B. Surlemont (2003), "Public Versus Private Venture Capital: Seeding or Crowding Out? A Pan-European Analysis", Journal of Business Venturing 18, 81-104.

Lerner, J. (2009), Boulevard of Broken Dreams, Princeton University Press, Princeton, NJ.

Marx, M., D. Strumsky, and L. Fleming (2009a), "Mobility, Skills, and the Michigan NonCompete Experiment", Management Science 55:6, 875-889.

Marx, M., J. Singh, and L. Fleming (2009b), "Does Non-compete Enforcement Create a Brain Drain?", HBS Working Paper.

Mayer, C., K. Schoors, and Y. Yafeh (2005), "Sources of Funds and Investment Activities of Venture Capital Funds: Evidence from Germany, Israel, Japan and the United Kingdom", Journal of Corporate Finance 11, 586-608.

Micco, A., and C. Pagés (2007), "The Economic Effects of Employment Protection: Evidence from International Industry-Level Data", IZA Working Paper.

OECD (2004), Employment Outlook: Employment Protection Regulation and Labour Market Performance, OECD Economics Department, Paris, France.

Parker, S. (2009), The Economics of Self-Employment and Entrepreneurship, Cambridge University Press, Cambridge, UK. 
Parker, S., and M. Robson (2004), "Explaining International Variations in Self-Employment: Evidence from a Panel of OECD Countries", Southern Economic Journal 71:2, 287-301.

Parker, S., and M. Van Praag (2010), "Group Status and Entrepreneurship", Journal of Economics and Management Strategy 19:4, 919-945.

Pissarides, C. (2001), "Employment Protection", Labour Economics 8, 131-159.

Puri, M., and R. Zarutskie (2011), "On the Lifecycle Dynamics of Venture-Capital- and NonVenture-Capital-Financed Firms", Journal of Finance, forthcoming.

Rajan, R., and L. Zingales (1998), "Financial Dependence and Growth", American Economic Review 88:3, 559-586.

Romain, A., and B. van Pottelsberghe (2004), "The Determinants of Venture Capital: Additional Evidence", Deutsche Bundesbank Working Paper 19/2004.

Sahlman, W. (1990), "The Structure and Governance of Venture Capital Organizations", Journal of Financial Economics 27, 473-521.

Saint-Paul, G. (1997), "Is Labor Rigidity Harming Europe's Competitiveness?", European Economic Review 41, 499-506.

Saint-Paul, G. (2002), "Employment Protection, International Specialization, and Innovation", European Economic Review 46, 375-395.

Samaniego, R. (2006), "Employment Protection and High-Tech Aversion", Review of Economic Dynamics 9, 224-241.

Samila, S., and O. Sorenson (2011a), "Noncompete Covenants: Incentives to Innovate or Impediments to Growth", Management Science 57:3, 425-438.

Samila, S., and O. Sorenson (2011b), "Venture Capital, Entrepreneurship and Economic Growth", Review of Economics and Statistics 93, 338-349.

Schoar, A. (2009), "The Divide Between Subsistence and Transformational Entrepreneurship", in Lerner, Josh, and Scott Stern (eds.) Innovation Policy and the Economy, Number 10 (Chicago, IL: University of Chicago Press, 2009), 57-71.

Simons, K., and T. Åstebro (2010), "Entrepreneurs Seeking Gains: Profit Motives and Risk Aversion in Inventors' Commercialization Decisions", Journal of Economics and Management Strategy 19:4, 863-888.

Stuart, T., and O. Sorenson (2003), "Liquidity Events and the Geographic Distribution of Organizational Foundings", Administrative Science Quarterly 48, 175-201.

Summers, L. (1989), "Some Simple Economics of Mandated Benefits", American Economic Review 79:2, 177-183.

Ueda, M., and M. Hirukawa (2008a), "Venture Capital and Industrial 'Innovation"”, Working Paper.

Ueda, M., and M. Hirukawa (2008b), "Venture Capital and Innovation: Which is First?", Working Paper.

Wolfers, J. (2010), "Employment Protection and Job Flows: Evidence from Seasonal Cycles", Economic Inquiry, forthcoming. 
Fig. 1a: Base worker insurance policies

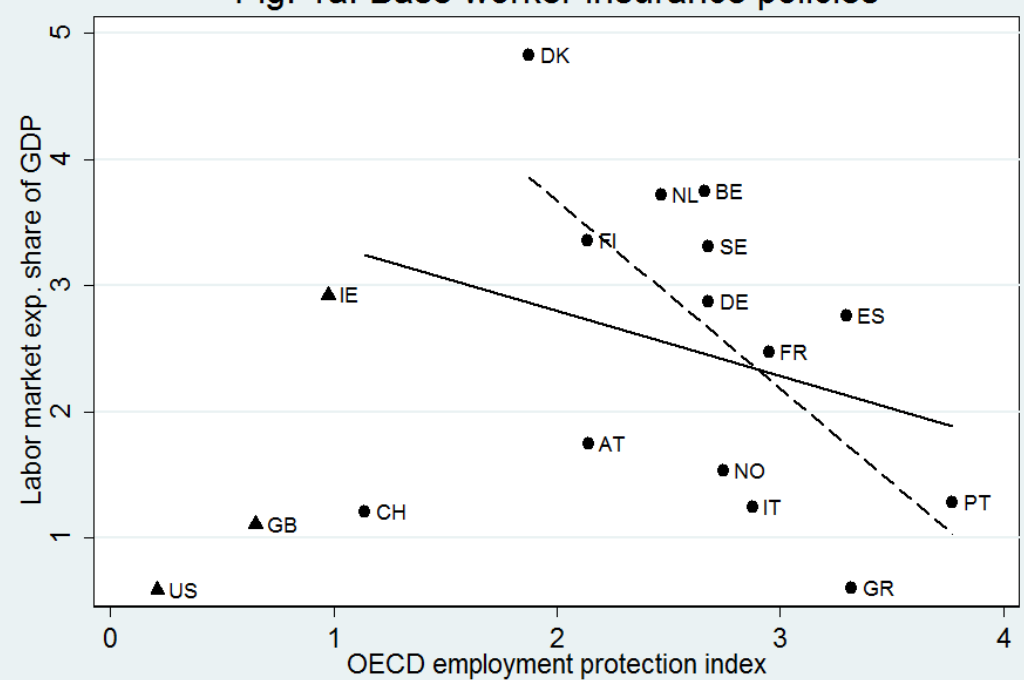

Fig. 1c: Venture capital \& employment protection

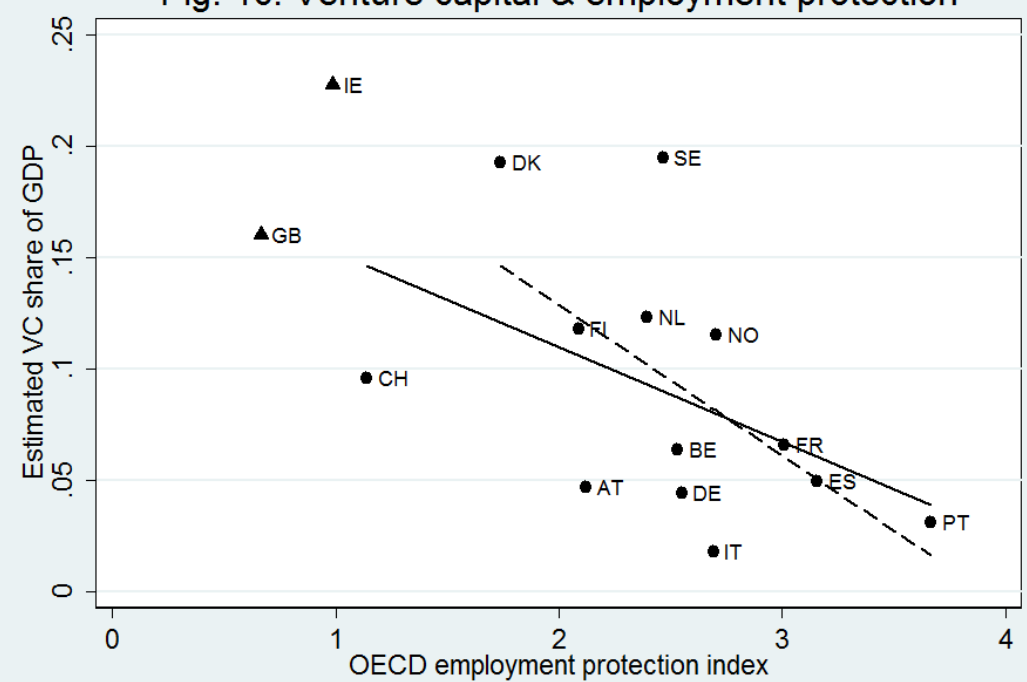

Fig. 1b: Transformed worker insurance policies

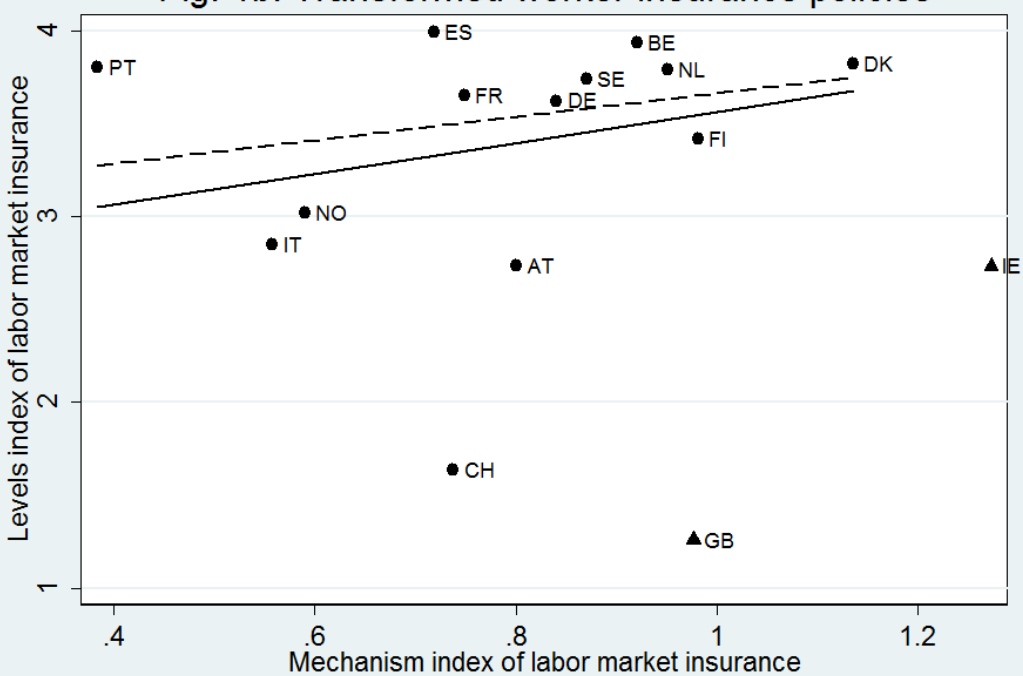

Fig. 1d: Venture capital \& labor mkt. expenditures

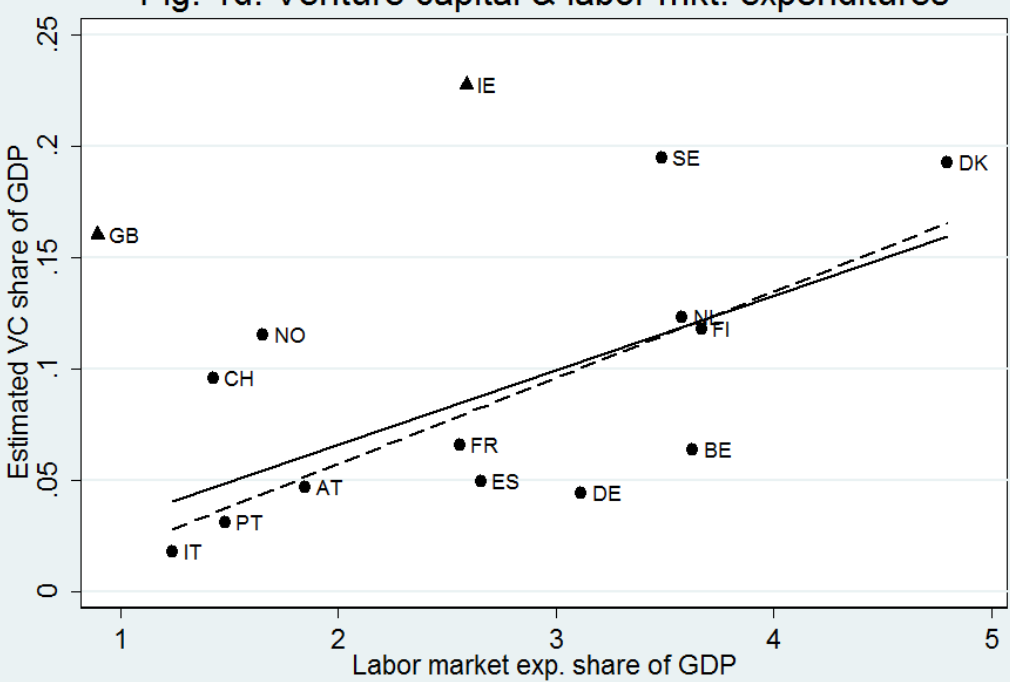

Notes: Figure 1a illustrates the policy trade-offs between employment protection and labor market expenditures (e.g., unemployment insurance benefits) as a share of GDP. Policies are averages over the 1990-2008 period. European nations generally provision greater worker insurance than Anglo-Saxon economies on both policy dimensions (e.g., Germany and France versus the US and UK). The solid trend line describes the policy trade-off for Continental European nations; the dashed line excludes Switzerland, which has insurance policies more similar to the Anglo-Saxon economies. European nations that favor employment protection systematically have lower labor market expenditures. Figure $1 \mathrm{~b}$ shows transformations of these policies into the Levels Index and Mechanism Index that are used in empirical analyses. Figures $1 \mathrm{c}$ and $1 \mathrm{~d}$ plot these base policies against estimated VC investments as a share of GDP for the 1990-2008 period. European nations favoring labor market expenditures over employment protection display stronger VC investment levels. 
Table 1A: Country-level descriptive statistics for European sample

\begin{tabular}{|c|c|c|c|c|c|}
\hline & $\begin{array}{c}\text { Employment } \\
\text { protection } \\
\text { index }\end{array}$ & $\begin{array}{l}\text { Labor market } \\
\text { expenditures } \\
\text { share of GDP }\end{array}$ & $\begin{array}{c}\text { Levels } \\
\text { index of } \\
\text { insurance }\end{array}$ & $\begin{array}{c}\text { Mechanism } \\
\text { index of } \\
\text { insurance }\end{array}$ & $\begin{array}{c}\text { Venture } \\
\text { capital } \\
\text { deals }\end{array}$ \\
\hline & $(1)$ & $(2)$ & (3) & (4) & (5) \\
\hline Austria & 2.1 & 1.9 & 2.8 & 0.8 & 330 \\
\hline Belgium & 2.5 & 3.6 & 3.8 & 0.9 & 520 \\
\hline Denmark & 1.7 & 4.8 & 3.7 & 1.2 & 782 \\
\hline Finland & 2.1 & 3.7 & 3.4 & 1.0 & 1334 \\
\hline France & 3.0 & 2.6 & 3.7 & 0.7 & 3368 \\
\hline Germany & 2.5 & 3.1 & 3.6 & 0.9 & 2381 \\
\hline Ireland & 1.0 & 2.6 & 2.5 & 1.2 & 634 \\
\hline Italy & 2.7 & 1.2 & 2.8 & 0.6 & 424 \\
\hline Netherlands & 2.4 & 3.6 & 3.6 & 0.9 & 995 \\
\hline Norway & 2.7 & 1.7 & 3.0 & 0.6 & 441 \\
\hline Portugal & 3.7 & 1.5 & 3.8 & 0.5 & 320 \\
\hline Spain & 3.1 & 2.7 & 3.8 & 0.7 & 678 \\
\hline Sweden & 2.5 & 3.5 & 3.6 & 0.9 & 1625 \\
\hline Switzerland & 1.1 & 1.4 & 1.8 & 0.9 & 502 \\
\hline UK & 0.7 & 0.9 & 1.0 & 0.8 & 5186 \\
\hline
\end{tabular}

Notes: Columns 1-4 provide average values over the 1990-2008 period. The employment protection regulations index is taken from the OECD and has a theoretical range of zero to five, with higher scores indicating stronger employment protection. Labor market expenditures as a share of GDP is derived from the OECD Social Expenditures and Labour Force databases. The Levels Index and Mechanism Index of labor market insurance are transformations of the employment protection and labor market expenditures policies. The Levels Index estimates the joint insurance provided through these two policies; higher values indicate greater worker insurance provision. The Mechanism Index estimates the relative importance of the two policies; higher values indicate greater reliance on labor market expenditures versus employment protection in the provision. VC deal counts are taken from the Venture Xpert database for the 1990-2008 period. Appendix Tables 1-3 provide additional details.
Table 1B: Sector-level descriptive statistics

\begin{tabular}{lcc}
\hline & $\begin{array}{c}\text { Venture } \\
\text { capital } \\
\text { deals }\end{array}$ & $\begin{array}{c}\text { US labor } \\
\text { volatility } \\
\text { in sector }\end{array}$ \\
\hline Computers & $(1)$ & $(2)$ \\
Communications & 4326 & 0.52 \\
Biotechnology & 3990 & 0.34 \\
Medical and health & 1969 & 0.43 \\
Consumer related & 1959 & 0.35 \\
Other electronics & 1942 & 0.41 \\
Other services & 917 & 0.36 \\
Industrial products & 678 & 0.41 \\
Other manufacturing & 488 & 0.31 \\
Financial services & 450 & 0.37 \\
Transportation & 410 & 0.40 \\
Energy & 365 & 0.35 \\
Chemicals and materials & 318 & 0.49 \\
Industrial automation & 307 & 0.28 \\
\hline Not VCd &
\end{tabular}

Notes: VC deal counts are taken from the Venture Xpert

database for the 1990-2008 period. US labor volatility metrics are calculated for establishments from the US Census Bureau data for 1977-1999. Volatility is defined as the mean absolute change in establishment employment from the previous year divided by the average employment in the current and previous years. Additional details on data sources and metric construction are available upon request from the authors. 
Table 2: Tabulations by investments shares by base country policy groups

Share of VC investments over the 1990-2008 period for each European country grouped by the sector's labor labor volatility in the United States
Full sample distribution
Countries split by insurance mechanisms

\begin{tabular}{ccc}
\hline $\begin{array}{c}\text { Countries } \\
\text { favoring }\end{array}$ & $\begin{array}{c}\text { Countries } \\
\text { favoring }\end{array}$ & $\begin{array}{c}\text { Difference } \\
\text { between }\end{array}$
\end{tabular}
employment labor market column 3 protection and column 2 expenditures

\section{Countries split by insurance levels}

\begin{tabular}{|c|c|c|c|c|c|}
\hline $\begin{array}{l}\text { ountries } \\
\text { avoring } \\
\text { ployment } \\
\text { otection }\end{array}$ & $\begin{array}{c}\text { Countries } \\
\text { favoring } \\
\text { labor market } \\
\text { expenditures }\end{array}$ & $\begin{array}{c}\text { Difference } \\
\text { between } \\
\text { column } 3 \\
\text { and column } 2\end{array}$ & $\begin{array}{l}\text { Countries } \\
\text { providing } \\
\text { lower labor } \\
\text { insurance }\end{array}$ & $\begin{array}{l}\text { Countries } \\
\text { providing } \\
\text { higher labor } \\
\text { insurance }\end{array}$ & $\begin{array}{c}\text { Difference } \\
\text { between } \\
\text { column } 6 \\
\text { and column } 5\end{array}$ \\
\hline (2) & (3) & (4) & (5) & (6) & $(7)$ \\
\hline $\begin{array}{l}0.353 \\
0.033)\end{array}$ & $\begin{array}{c}0.415 \\
(0.019)\end{array}$ & $\begin{array}{c}0.062 \\
(0.038)\end{array}$ & $\begin{array}{c}0.384 \\
(0.028)\end{array}$ & $\begin{array}{c}0.379 \\
(0.033)\end{array}$ & $\begin{array}{l}-0.004 \\
(0.043)\end{array}$ \\
\hline $\begin{array}{l}0.290 \\
0.037)\end{array}$ & $\begin{array}{c}0.211 \\
(0.016)\end{array}$ & $\begin{array}{l}-0.079 \\
(0.040)\end{array}$ & $\begin{array}{c}0.231 \\
(0.024)\end{array}$ & $\begin{array}{c}0.277 \\
(0.041)\end{array}$ & $\begin{array}{c}0.046 \\
(0.048)\end{array}$ \\
\hline $\begin{array}{l}0.357 \\
0.020)\end{array}$ & $\begin{array}{c}0.374 \\
(0.014)\end{array}$ & $\begin{array}{c}0.017 \\
(0.025)\end{array}$ & $\begin{array}{c}0.385 \\
(0.019)\end{array}$ & $\begin{array}{c}0.343 \\
(0.012)\end{array}$ & $\begin{array}{l}-0.042 \\
(0.022)\end{array}$ \\
\hline
\end{tabular}

Notes: Tabulations describe the distribution of investments made by countries across sectors of various volatilities during the $1990-2008$ period. Countries are split based upon their average policy positions during the period using the median values observed across all countries. The split in Columns $2-4$ uses the Mechanism Index of labor insurance. Countries in Column 2 favor employment protection relatively more, given their overall level of insurance provided, and include AUT, ESP, FRA, GBR, ITA, NOR, PRT, and SWE. Countries in Column 3 favor labor market expenditures relatively more, given their overall level of insurance provided, and include BEL, CHE, DEU, DNK, FIN, IRE, and NLD. Column 4 provides the linear difference between these two groups that allows for unequal variance. The split in Columns 5-7 uses the Levels Index of labor insurance. Countries in Column 5 provide generally lower labor market insurance, considering both policies together, and include AUT, CHE, FIN, GBR, IRE, ITA, NOR, and SWE. Countries in Column 6 provide higher insurance levels and include BEL, DEU, DNK, ESP, FRA, NLD, and PRT. Column 7 provides the linear difference between these two groups that allows for unequal variance. Sectors are split by labor volatility as observed in the United States across the 1977-1999 period. High-volatility sectors include Biotechnology, Computers, Energy, and Other services. Medium-volatility sectors include Consumer related, Financial services, Other electronics, Other manufacturing, and Transportation. Low-volatility sectors include Chemicals and materials,

Communications, Industrial automation, Industrial products, and Medical and health. Tables $1 \mathrm{~A}$ and 1B provide underlying values. 
Table 3: Labor volatility of VC-backed companies in Europe

\begin{tabular}{|c|c|c|c|c|c|c|}
\hline & \multicolumn{6}{|c|}{ Dependent variable is labor volatility of firm in unit standard deviations } \\
\hline & (1) & $(2)$ & (3) & (4) & $(5)$ & (6) \\
\hline $\begin{array}{l}\text { Indicator variable for } \mathrm{VC} \\
\text { investment in the firm }\end{array}$ & $\begin{array}{c}0.292 \\
(0.024)\end{array}$ & $\begin{array}{c}0.226 \\
(0.023)\end{array}$ & $\begin{array}{c}0.245 \\
(0.023)\end{array}$ & $\begin{array}{c}0.170 \\
(0.027)\end{array}$ & $\begin{array}{c}0.209 \\
(0.026)\end{array}$ & $\begin{array}{c}0.231 \\
(0.026)\end{array}$ \\
\hline $\begin{array}{l}\text { Sample employed } \\
\text { Country-industry-year fixed effects } \\
\text { Firm size and revenue covariates } \\
\text { Observations }\end{array}$ & $2,350,850$ & $\begin{array}{l}\text { Full } \\
\text { Yes }\end{array}$ & $\begin{array}{l}\text { Full } \\
\text { Yes } \\
\text { Yes } \\
2,350,850\end{array}$ & 102,144 & $\begin{array}{l}\text { Restricted } \\
\text { Yes } \\
\text { Yes } \\
102,144\end{array}$ & $\begin{array}{l}\text { Matched } \\
\text { Yes } \\
\text { Yes } \\
9,659\end{array}$ \\
\hline $\begin{array}{l}\text { Notes: Firm-year estimations consider } 1 \\
\text { Dependent variables are the absolute val } \\
\text { of the firm in the current and previous y } \\
\text { interpretation. The explanatory variable } \\
\text { industry-year fixed effects (where indica } \\
\text { Standard Industrial Classification systen } \\
\text { restricted sample in Columns } 4-5 \text { only in } \\
\text { The matched sample in Column } 6 \text { create }\end{array}$ & $\begin{array}{l}\text { yment chang } \\
\text { olatility mea } \\
\text { or variable fo } \\
\text { ter standard } \\
\text { and revenues } \\
\text { ry-industry p } \\
\text { oup that mos }\end{array}$ & $\begin{array}{l}s \text { by firm fro } \\
\text { ures are tran } \\
\text { the firm bei } \\
\text { trors by cour } \\
\text { covariates in } \\
\text { irs where VC } \\
\text { closely mat }\end{array}$ & $\begin{array}{l}\text { the prior yea } \\
\text { ormed to hav } \\
\mathrm{g} \text { backed by } \\
\text { y. Industries } \\
\text { ude log empl } \\
\text { ownership is } \\
\text { es the employ }\end{array}$ & $\begin{array}{l}\text { relative to the } \\
\text { unit standard } \\
\text { C investors. } \\
\text { are defined at } \\
\text { yment and log } \\
\text { dentified in gr } \\
\text { ment and reve }\end{array}$ & $\begin{array}{l}\text { average emp } \\
\text { deviation for } \\
\text { egressions in } \\
\text { he three-digi } \\
\text { revenues of } \mathrm{f} \\
\text { ater than } 1 \% \\
\text { ues of } \mathrm{VC} p\end{array}$ & $\begin{array}{l}\text { atabase. } \\
\text { yment level } \\
\text { ude country. } \\
\text { evel of the } \\
\text { ns. The } \\
\text { the firms. } \\
\text { folio firms }\end{array}$ \\
\hline
\end{tabular}

\section{Table 4: Selection and traits of VC-backed companies in Europe}

\begin{tabular}{lccccccc}
\hline & \multicolumn{2}{c}{$\begin{array}{c}\text { Dep. variable is indicator for VC investments in unit standard deviations } \\
\text { Coefficients are from a single regression that includes each variable } \\
\text { indicated by column headers interacted as described in the rows }\end{array}$} \\
& $\begin{array}{c}\text { Employ- } \\
\text { ment }\end{array}$ & $\begin{array}{c}\text { Revenues } \\
\text { Assets per } \\
\text { employee }\end{array}$ & $\begin{array}{c}\text { Firm } \\
\text { age }\end{array}$ & $\begin{array}{c}\text { Wage } \\
\text { EBITDA } \\
\text { margin }\end{array}$ \\
\cline { 2 - 8 } & $(1)$ & $(2)$ & $(3)$ & $(4)$ & $(5)$ & $(6)$ \\
\hline Firm trait indicated in column headers & 0.096 & -0.078 & 0.053 & -0.029 & 0.025 & -0.017 \\
& $(0.031)$ & $(0.032)$ & $(0.021)$ & $(0.009)$ & $(0.009)$ & $(0.007)$ \\
Indicated firm trait & 0.008 & -0.011 & 0.009 & -0.003 & 0.005 & -0.001 \\
x time-invariant US labor volatility by sector & $(0.003)$ & $(0.006)$ & $(0.005)$ & $(0.002)$ & $(0.006)$ & $(0.002)$ \\
Indicated firm trait & -0.021 & 0.033 & -0.004 & 0.007 & -0.010 & 0.004 \\
x nation's employment protection index & $(0.020)$ & $(0.021)$ & $(0.014)$ & $(0.006)$ & $(0.005)$ & $(0.005)$ \\
Indicated firm trait & -0.018 & 0.013 & -0.005 & 0.004 & -0.006 & 0.004
\end{tabular}

$\mathrm{x}$ nation's employment protection index

Notes: Coefficients are from a single regression of VC investment in Europe for 1999-2008 using the Amadeus database. The dependent variable is an indicator variable for VC investments in firms transformed to have unit standard deviation for interpretation. Explanatory variables are indicated firm traits (noted by column sub-headers) and their interactions with sector volatilities and OECD employment protection indices for countries. Variables are demeaned and transformed to have unit standard deviation before interaction. Firm traits are winsorized at their $2 \% / 98 \%$ values by country-industry-year. The regression includes country-industry-year fixed effects, clusters standard errors by country, and contains 2,053,302 observations where all firm traits are recorded. Industries are defined at the three-digit level of the Standard Industrial Classification system. Country-industry-year fixed effects absorb policy and sector volatility main effects. 
Dependent variable is VC investment in the country-sector-period

$\begin{array}{cccccc}\begin{array}{c}\text { Extensive } \\ \text { margin }\end{array} & \begin{array}{c}\text { Log count } \\ \text { of VC }\end{array} & \begin{array}{c}\text { Log value } \\ \text { of VC }\end{array} & \begin{array}{c}\text { Extensive } \\ \text { margin }\end{array} & \begin{array}{c}\text { Log count } \\ \text { of VC }\end{array} & \begin{array}{c}\text { Log value } \\ \text { of VC }\end{array} \\ & \text { investments investments } & & & \text { investments investments }\end{array}$

(1)

(2)
(3)
(5)

A. Estimations using base policies

$\begin{array}{lcccccc}\text { OECD employment protection index } & -0.034 & -0.127 & -0.143 & -0.028 & -0.098 & -0.111 \\ \text { x time-invariant US labor volatility by sector } & (0.012) & (0.057) & (0.083) & (0.012) & (0.056) & (0.082) \\ \text { Labor market expenditures } & 0.021 & 0.073 & 0.088 & 0.019 & 0.064 & 0.075 \\ \text { x time-invariant US labor volatility by sector } & (0.017) & (0.039) & (0.062) & (0.017) & (0.050) & (0.072) \\ \text { Sector-period fixed effects } & \text { Yes } & \text { Yes } & \text { Yes } & \text { Yes } & \text { Yes } & \text { Yes } \\ \text { Country-period fixed effects } & \text { Yes } & \text { Yes } & \text { Yes } & \text { Yes } & \text { Yes } & \text { Yes } \\ \text { Additional controls } & & & & \text { Yes } & \text { Yes } & \text { Yes } \\ \text { Observations } & 840 & 671 & 671 & 840 & 671 & 671 \\ \text { Linear combination for policy mechanism: } & 0.054 & 0.200 & 0.231 & 0.047 & 0.162 & 0.186 \\ \beta \text { [Labor market exp.] - } \beta \text { [Employment protection] } & (0.027) & (0.079) & (0.126) & (0.027) & (0.093) & (0.139)\end{array}$

B. Estimations using transformed policies

$\begin{array}{lcccccc}\text { Mechanism index of labor market insurance } & 0.033 & 0.099 & 0.116 & 0.028 & 0.083 & 0.095 \\ \text { x time-invariant US labor volatility by sector } & (0.009) & (0.034) & (0.050) & (0.009) & (0.038) & (0.054) \\ \text { Levels index of labor market insurance } & -0.009 & -0.043 & -0.044 & -0.006 & -0.029 & -0.030 \\ \text { x time-invariant US labor volatility by sector } & (0.008) & (0.040) & (0.054) & (0.008) & (0.036) & (0.049) \\ \text { Sector-period fixed effects } & \text { Yes } & \text { Yes } & \text { Yes } & \text { Yes } & \text { Yes } & \text { Yes } \\ \text { Country-period fixed effects } & \text { Yes } & \text { Yes } & \text { Yes } & \text { Yes } & \text { Yes } & \text { Yes } \\ \text { Additional controls } & & & & \text { Yes } & \text { Yes } & \text { Yes } \\ \text { Observations } & 840 & 671 & 671 & 840 & 671 & 671\end{array}$

Notes: Estimations consider VC investments in Europe for 1990-2008 by country-sector-period. The four time periods are 1990-1994, 1995-1999, 2000-2004, and 2005-2008. The dependent variables are an indicator variable for one or more VC investments on average per annum in the country-sector during the period, the log count of VC investments, and the estimated log value of VC investments. Panel A presents estimations that employ base employment protection and labor market insurance expenditure variables. These countryperiod explanatory variables are interacted with the time-invariant sector-level labor volatility of establishments in the US measured 19771999. The bottom row presents the linear difference $\beta$ [Labor market exp.] - $\beta$ [Employment protection] and its standard error for the interaction with sector labor volatility. This difference approximates a policy change that holds the level of worker insurance provided constant but adjusts the insurance mechanism from employment protection towards labor market expenditures. Panel B presents estimations that employ transformed policy metrics. The Mechanism Index of labor market insurance measures the extent to which a nation's policies favor labor market expenditures (e.g., unemployment insurance benefits) over employment protection as the mechanism for providing worker insurance in the economy. The Levels Index measures the total insurance provided by these two policies. Main effects are demeaned prior to interactions and are absorbed by fixed effects. Variables are transformed to have unit standard deviation for interpretation. Regressions are weighted by country populations interacted with aggregate sector size. Columns 1-3 present estimations without country-sector covariates; columns 4-6 include these covariates. Additional covariates include log patents in the country-sectorperiod, the lagged IPO share in country-sector-period, seed and early stage investment shares in country-sector-period, and log estimates of country-sector size and wage developed from Amadeus for 1999-2008. Standard errors are clustered by country. 
Dependent variable is VC investment in the country-sector-period Extensive Log count Log value Extensive Log count Log value margin of $\mathrm{VC}$ of $\mathrm{VC}$ margin of $\mathrm{VC}$ of $\mathrm{VC}$ investments investments investments investments

(1) (2)

(3)

(4)

(5) (6)

A. Estimations using base policies

\begin{tabular}{|c|c|c|c|c|c|c|}
\hline OECD employment protection index & $\begin{array}{l}-0.320 \\
(0.107)\end{array}$ & $\begin{array}{l}-0.330 \\
(0.190)\end{array}$ & $\begin{array}{l}-0.121 \\
(0.217)\end{array}$ & $\begin{array}{l}-0.284 \\
(0.097)\end{array}$ & $\begin{array}{l}-0.282 \\
(0.186)\end{array}$ & $\begin{array}{l}-0.085 \\
(0.209)\end{array}$ \\
\hline $\begin{array}{l}\text { OECD employment protection index } \\
\mathrm{x} \text { time-invariant US labor volatility by sector }\end{array}$ & $\begin{array}{l}-0.111 \\
(0.051)\end{array}$ & $\begin{array}{l}-0.089 \\
(0.061)\end{array}$ & $\begin{array}{l}-0.067 \\
(0.050)\end{array}$ & $\begin{array}{l}-0.110 \\
(0.048)\end{array}$ & $\begin{array}{l}-0.109 \\
(0.065)\end{array}$ & $\begin{array}{l}-0.086 \\
(0.051)\end{array}$ \\
\hline Labor market expenditures & $\begin{array}{c}0.137 \\
(0.058)\end{array}$ & $\begin{array}{c}0.018 \\
(0.111)\end{array}$ & $\begin{array}{c}0.015 \\
(0.158)\end{array}$ & $\begin{array}{c}0.121 \\
(0.049)\end{array}$ & $\begin{array}{c}0.009 \\
(0.104)\end{array}$ & $\begin{array}{c}0.011 \\
(0.143)\end{array}$ \\
\hline $\begin{array}{l}\text { Labor market expenditures } \\
\mathrm{x} \text { time-invariant US labor volatility by sector }\end{array}$ & $\begin{array}{c}0.037 \\
(0.059)\end{array}$ & $\begin{array}{c}0.085 \\
(0.105)\end{array}$ & $\begin{array}{c}0.164 \\
(0.130)\end{array}$ & $\begin{array}{c}0.028 \\
(0.059)\end{array}$ & $\begin{array}{c}0.074 \\
(0.110)\end{array}$ & $\begin{array}{c}0.155 \\
(0.130)\end{array}$ \\
\hline Country-sector fixed effects & Yes & Yes & Yes & Yes & Yes & Yes \\
\hline Sector-period fixed effects & Yes & Yes & Yes & Yes & Yes & Yes \\
\hline Log country GDP control & Yes & Yes & Yes & Yes & Yes & Yes \\
\hline Additional controls & & & & Yes & Yes & Yes \\
\hline Observations & 840 & 671 & 671 & 840 & 671 & 671 \\
\hline Linear combination for policy mechanism: & 0.148 & 0.174 & 0.231 & 0.137 & 0.184 & 0.241 \\
\hline$\beta[$ Labor market exp.] - $\beta[$ Employment protection $]$ & $(0.059)$ & $(0.107)$ & $(0.112)$ & $(0.051)$ & $(0.098)$ & $(0.105)$ \\
\hline
\end{tabular}

B. Estimations using transformed policies

Mechanism index of labor market insurance

$\begin{array}{lllll}0.154 & 0.134 & 0.097 & 0.135 & 0.118\end{array}$

$\begin{array}{lllll}(0.022) & (0.053) & (0.070) & (0.020) & (0.054)\end{array}$

0.091

Mechanism index of labor market insurance

0.048

0.059

0.073

0.044

0.063

0.076

$\mathrm{x}$ time-invariant US labor volatility by sector

(0.009)

(0.012)

(0.018)

(0.009)

(0.013)

(0.018)

Levels index of labor market insurance

$-0.159$

$-0.185$

0.011

$-0.139$

$-0.173$

0.013

(0.133)

(0.194)

(0.187)

(0.116)

(0.179)

$(0.169)$

Levels index of labor market insurance

$-0.044$

$-0.007$

0.032

$-0.052$

$-0.027$

0.016

$\mathrm{x}$ time-invariant US labor volatility by sector

(0.070)

(0.080)

(0.114)

(0.074)

(0.094)

$(0.116)$

Country-sector fixed effects

$\begin{array}{lll}\text { Yes } & \text { Yes } & \text { Yes } \\ \text { Yes } & \text { Yes } & \text { Yes } \\ \text { Yes } & \text { Yes } & \text { Yes }\end{array}$

Loctor-period fixed effects

Log country GDP control

Additional controls

Observations

840

671

671

Yes
Yes
Yes
Yes
840

Yes

Yes

Yes

Yes

Yes Yes

Yes Yes

Notes: See Table 5. Estimates include country-sector and sector-period fixed effects to consider longitudinal changes within countrysectors. These estimations identify longitudinal responses at the country level and the differentials that exist by time-invariant US sector volatility. 
Dependent variable is VC investment in the country-sector-period Extensive Log count Log value Extensive Log count Log value margin of $\mathrm{VC}$ of $\mathrm{VC}$ margin of $\mathrm{VC}$ of $\mathrm{VC}$ investments investments investments investments

\section{(1)}

(2)

(3)

(4)

(5)

A. Estimations using base policies

$\begin{array}{lcccccc}\text { OECD employment protection index } & -0.111 & -0.093 & -0.077 & -0.110 & -0.103 & -0.084 \\ \text { x time-invariant US labor volatility by sector } & (0.052) & (0.087) & (0.090) & (0.048) & (0.077) & (0.075) \\ \text { Labor market expenditures } & 0.037 & 0.117 & 0.207 & 0.027 & 0.105 & 0.195 \\ \text { x time-invariant US labor volatility by sector } & (0.061) & (0.119) & (0.142) & (0.061) & (0.121) & (0.142) \\ \text { Country-sector fixed effects } & \text { Yes } & \text { Yes } & \text { Yes } & \text { Yes } & \text { Yes } & \text { Yes } \\ \text { Sector-period fixed effects } & \text { Yes } & \text { Yes } & \text { Yes } & \text { Yes } & \text { Yes } & \text { Yes } \\ \text { Country-period fixed effects } & \text { Yes } & \text { Yes } & \text { Yes } & \text { Yes } & \text { Yes } & \text { Yes } \\ \text { Additional controls } & & & & \text { Yes } & \text { Yes } & \text { Yes } \\ \text { Observations } & 840 & 671 & 671 & 840 & 671 & 671 \\ \text { Linear combination for policy mechanism: } & 0.148 & 0.210 & 0.283 & 0.136 & 0.208 & 0.279 \\ \beta \text { BLabor market exp.] - } \beta \text { [Employment protection] } & (0.061) & (0.131) & (0.142) & (0.054) & (0.119) & (0.134)\end{array}$

B. Estimations using transformed policies

$\begin{array}{lcccccc}\text { Mechanism index of labor market insurance } & 0.048 & 0.072 & 0.091 & 0.043 & 0.071 & 0.088 \\ \text { x time-invariant US labor volatility by sector } & (0.009) & (0.019) & (0.020) & (0.009) & (0.018) & (0.019) \\ \text { Levels index of labor market insurance } & -0.044 & 0.021 & 0.072 & -0.051 & 0.005 & 0.060 \\ \text { x time-invariant US labor volatility by sector } & (0.073) & (0.110) & (0.135) & (0.075) & (0.112) & (0.134) \\ \text { Country-sector fixed effects } & \text { Yes } & \text { Yes } & \text { Yes } & \text { Yes } & \text { Yes } & \text { Yes } \\ \text { Sector-period fixed effects } & \text { Yes } & \text { Yes } & \text { Yes } & \text { Yes } & \text { Yes } & \text { Yes } \\ \text { Country-period fixed effects } & \text { Yes } & \text { Yes } & \text { Yes } & \text { Yes } & \text { Yes } & \text { Yes } \\ \text { Additional controls } & & & & \text { Yes } & \text { Yes } & \text { Yes } \\ \text { Observations } & 840 & 671 & 671 & 840 & 671 & 671\end{array}$

Notes: See Table 5. Estimates include country-sector fixed effects, sector-period fixed effects, and country-period fixed effects in a tripledifferencing approach. Estimations require that a within-country shift in worker insurance policies towards more flexible techniques connect with an increase in VC financing (the first differencing due to country-sector fixed effects, a longitudinal response) that exceeds the overall sector growth worldwide (the second differencing due to sector-year fixed effects) and that is strongest in sectors with greater intrinsic labor volatility (the third differencing due to country-year fixed effects). Sector volatility is time-invariant and measured using US data, so that changes are only being identified through policies. 
Table 8: Robustness checks on longitudinal results

Dependent variable is VC investment in the country-sector-period

Using Excluding Excluding Excluding Examining Examining US sector sample UK and computer EVCA linear volatility weights Ireland sector totals indices

(2)

(3)

(4)

(5)

(6)

A. Entry specification in Column 1 of Panel B of Table 6

Mechanism index of labor market insurance
0.136
0.084
0.240
0.135
0.030
0.116
(0.020)
(0.028)
(0.092)
(0.021)
(0.011)
(0.020)

Mechanism index of labor market insurance

0.025

0.020

0.054

0.048

$-0.004$

0.034

$\mathrm{x}$ time-invariant US labor volatility by sector

(0.011)

$(0.021)$

(0.045)

(0.026)

(0.007)

(0.013)

Levels index of labor market insurance

$-0.141$

$-0.099$

$-0.164$

$-0.126$

$-0.002$

$-0.157$

$(0.118)$

(0.080)

(0.090)

(0.127)

(0.062)

(0.111)

Levels index of labor market insurance

$-0.044$

$-0.027$

$-0.080$

$-0.017$

0.018

$-0.069$

$\mathrm{x}$ time-invariant US labor volatility by sector

(0.049)

$(0.044)$

$(0.069)$

$(0.127)$

$(0.037)$

(0.059)

Country-sector fixed effects

Sector-period fixed effects

Log country GDP control

Additional controls

Observations

$\begin{array}{lllccc}\text { Yes } & \text { Yes } & \text { Yes } & \text { Yes } & \text { Yes } & \text { Yes } \\ \text { Yes } & \text { Yes } & \text { Yes } & \text { Yes } & \text { Yes } & \text { Yes } \\ \text { Yes } & \text { Yes } & \text { Yes } & \text { Yes } & \text { Yes } & \text { Yes } \\ \text { Yes } & \text { Yes } & \text { Yes } & \text { Yes } & \text { Yes } & \text { Yes } \\ 840 & 840 & 728 & 780 & 540 & 840\end{array}$

B. Count specification in Column 2 of Panel B of Table 6

$\begin{array}{lcccccc}\text { Mechanism index of labor market insurance } & 0.121 & 0.033 & 0.139 & 0.123 & 0.146 & 0.096 \\ & (0.055) & (0.079) & (0.188) & (0.067) & (0.054) & (0.044) \\ \text { Mechanism index of labor market insurance } & 0.043 & 0.043 & -0.032 & 0.086 & 0.007 & 0.057 \\ \text { x time-invariant US labor volatility by sector } & (0.020) & (0.027) & (0.124) & (0.057) & (0.012) & (0.021) \\ \text { Levels index of labor market insurance } & -0.173 & -0.262 & -0.232 & -0.221 & -0.024 & -0.176 \\ & (0.181) & (0.252) & (0.171) & (0.239) & (0.310) & (0.179) \\ \text { Levels index of labor market insurance } & 0.026 & -0.048 & -0.131 & -0.147 & -0.028 & -0.041 \\ \text { x time-invariant US labor volatility by sector } & (0.080) & (0.114) & (0.121) & (0.296) & (0.065) & (0.069) \\ \text { Country-sector fixed effects } & \text { Yes } & \text { Yes } & \text { Yes } & \text { Yes } & \text { Yes } & \text { Yes } \\ \text { Sector-period fixed effects } & \text { Yes } & \text { Yes } & \text { Yes } & \text { Yes } & \text { Yes } & \text { Yes } \\ \text { Log country GDP control } & \text { Yes } & \text { Yes } & \text { Yes } & \text { Yes } & \text { Yes } & \text { Yes } \\ \text { Additional controls } & \text { Yes } & \text { Yes } & \text { Yes } & \text { Yes } & \text { Yes } & \text { Yes } \\ \text { Observations } & 671 & 671 & 576 & 616 & 530 & 671\end{array}$

Notes: See Table 6. Panel A shows robustness checks on the entry specification from Column 1 of Panel B of Table 6. Panel B shows robustness checks on the count specification from Column 2 of Panel B of Table 6. 
Table 9: Robustness checks on longitudinal results, continued

Dependent variable is VC investment in the country-sector-period

\begin{tabular}{cccccc}
$\begin{array}{c}\text { Including } \\
\text { public } \\
\begin{array}{c}\text { R\&D share } \\
\text { of GDP }\end{array}\end{array}$ & $\begin{array}{c}\text { Including } \\
\text { corporate }\end{array}$ & $\begin{array}{c}\text { Including } \\
\text { bankruptcy } \\
\text { discharge } \\
\text { stringency }\end{array}$ & $\begin{array}{c}\text { Including } \\
\text { required } \\
\text { minimum } \\
\text { capital }\end{array}$ & $\begin{array}{c}\text { Including } \\
\text { public } \\
\text { venturing } \\
\text { shares }\end{array}$ & $\begin{array}{c}\text { Including } \\
\text { time trends } \\
\text { for legal } \\
\text { origins }\end{array}$ \\
\hline$(1)$ & $(2)$ & $(3)$ & $(4)$ & $(5)$ & $(6)$ \\
\hline
\end{tabular}

A. Entry specification in Column 1 of Panel B of Table 6

$\begin{array}{lcccccc}\text { Mechanism index of labor market insurance } & 0.124 & 0.143 & 0.124 & 0.129 & 0.137 & 0.125 \\ & (0.022) & (0.016) & (0.022) & (0.019) & (0.022) & (0.035) \\ \text { Mechanism index of labor market insurance } & 0.037 & 0.036 & 0.036 & 0.043 & 0.046 & 0.044 \\ \text { x time-invariant US labor volatility by sector } & (0.006) & (0.007) & (0.006) & (0.010) & (0.010) & (0.009) \\ \text { Levels index of labor market insurance } & -0.119 & -0.169 & -0.137 & -0.102 & -0.148 & -0.143 \\ & (0.086) & (0.102) & (0.099) & (0.110) & (0.123) & (0.115) \\ \text { Levels index of labor market insurance } & -0.040 & -0.032 & -0.053 & -0.055 & -0.065 & -0.052 \\ \text { x time-invariant US labor volatility by sector } & (0.074) & (0.081) & (0.073) & (0.091) & (0.072) & (0.074) \\ \text { Country-sector fixed effects } & \text { Yes } & \text { Yes } & \text { Yes } & \text { Yes } & \text { Yes } & \text { Yes } \\ \text { Sector-period fixed effects } & \text { Yes } & \text { Yes } & \text { Yes } & \text { Yes } & \text { Yes } & \text { Yes } \\ \text { Log country GDP control } & \text { Yes } & \text { Yes } & \text { Yes } & \text { Yes } & \text { Yes } & \text { Yes } \\ \text { Additional controls } & \text { Yes } & \text { Yes } & \text { Yes } & \text { Yes } & \text { Yes } & \text { Yes } \\ \text { Observations } & 840 & 840 & 672 & 672 & 840 & 840\end{array}$

B. Count specification in Column 2 of Panel B of Table 6

$\begin{array}{lcccccc}\text { Mechanism index of labor market insurance } & 0.106 & 0.131 & 0.108 & 0.115 & 0.130 & 0.126 \\ & (0.057) & (0.047) & (0.052) & (0.054) & (0.061) & (0.099) \\ \text { Mechanism index of labor market insurance } & 0.056 & 0.068 & 0.065 & 0.061 & 0.068 & 0.064 \\ \text { x time-invariant US labor volatility by sector } & (0.014) & (0.022) & (0.011) & (0.014) & (0.021) & (0.013) \\ \text { Levels index of labor market insurance } & -0.148 & -0.230 & -0.131 & -0.083 & -0.224 & -0.111 \\ & (0.167) & (0.209) & (0.132) & (0.158) & (0.170) & (0.119) \\ \text { Levels index of labor market insurance } & -0.008 & -0.049 & -0.046 & -0.069 & -0.038 & -0.028 \\ \text { x time-invariant US labor volatility by sector } & (0.106) & (0.141) & (0.101) & (0.107) & (0.114) & (0.093) \\ \text { Country-sector fixed effects } & \text { Yes } & \text { Yes } & \text { Yes } & \text { Yes } & \text { Yes } & \text { Yes } \\ \text { Sector-period fixed effects } & \text { Yes } & \text { Yes } & \text { Yes } & \text { Yes } & \text { Yes } & \text { Yes } \\ \text { Log country GDP control } & \text { Yes } & \text { Yes } & \text { Yes } & \text { Yes } & \text { Yes } & \text { Yes } \\ \text { Additional controls } & \text { Yes } & \text { Yes } & \text { Yes } & \text { Yes } & \text { Yes } & \text { Yes } \\ \text { Observations } & 671 & 671 & 555 & 555 & 671 & 671\end{array}$

Notes: See Table 6. Panel A shows robustness checks on the entry specification from Column 1 of Panel B of Table 6. Panel B shows robustness checks on the count specification from Column 2 of Panel B of Table 6. 


\begin{tabular}{|c|c|c|}
\hline & \multicolumn{2}{|c|}{$\mathrm{DV}$ is VC investment in the country-sector-period } \\
\hline & Extensive margin & Log count of investments \\
\hline & $(1)$ & (2) \\
\hline Mechanism index of labor market insurance & $\begin{array}{c}0.151 \\
(0.019)\end{array}$ & $\begin{array}{c}0.167 \\
(0.035)\end{array}$ \\
\hline Levels index of labor market insurance & $\begin{array}{l}-0.249 \\
(0.106)\end{array}$ & $\begin{array}{l}-0.355 \\
(0.100)\end{array}$ \\
\hline Public R\&D share of GDP & $\begin{array}{c}0.104 \\
(0.082)\end{array}$ & $\begin{array}{c}0.059 \\
(0.163)\end{array}$ \\
\hline Corporate tax rate & $\begin{array}{c}0.156 \\
(0.045)\end{array}$ & $\begin{array}{c}0.279 \\
(0.087)\end{array}$ \\
\hline Stringency of bankruptcy discharge laws & $\begin{array}{l}-0.096 \\
(0.046)\end{array}$ & $\begin{array}{l}-0.166 \\
(0.061)\end{array}$ \\
\hline Minimum capital requirement laws & $\begin{array}{c}0.122 \\
(0.146)\end{array}$ & $\begin{array}{c}0.332 \\
(0.239)\end{array}$ \\
\hline Public venturing share of investments & $\begin{array}{c}0.070 \\
(0.061)\end{array}$ & $\begin{array}{c}0.202 \\
(0.088)\end{array}$ \\
\hline Log patent counts & $\begin{array}{l}-0.010 \\
(0.060)\end{array}$ & $\begin{array}{l}-0.089 \\
(0.097)\end{array}$ \\
\hline Lagged past IPO success of ventures & $\begin{array}{c}0.176 \\
(0.080)\end{array}$ & $\begin{array}{c}0.242 \\
(0.224)\end{array}$ \\
\hline Seed stage share of investments & $\begin{array}{c}0.238 \\
(0.204)\end{array}$ & $\begin{array}{c}0.790 \\
(0.335)\end{array}$ \\
\hline Early stage share of investments & $\begin{array}{c}0.270 \\
(0.173)\end{array}$ & $\begin{array}{l}-0.249 \\
(0.422)\end{array}$ \\
\hline Log country GDP & $\begin{array}{c}0.900 \\
(0.204)\end{array}$ & $\begin{array}{c}2.029 \\
(0.719)\end{array}$ \\
\hline Country-sector fixed effects & Yes & Yes \\
\hline Sector-period fixed effects & Yes & Yes \\
\hline Observations & 672 & 555 \\
\hline
\end{tabular}

Notes: See Tables 6 and 9. Estimations consider VC investments in Europe for 1990-2008 by country-sector-period. The four time periods are 1990-1994, 1995-1999, 2000-2004, and 2005-2008. The dependent variable in Column 1 is an indicator variable for one or more VC investments on average per annum in the country-sector during the period. The dependent variable in Column 2 is the log count of VC investments. The Mechanism Index of labor market insurance measures the extent to which a nation's policies favor labor market expenditures (e.g., unemployment insurance benefits) over employment protection as the mechanism for providing worker insurance in the economy. The Levels Index measures the total insurance provided by these two policies. Variables are transformed to have unit standard deviation for interpretation. Regressions are weighted by country populations interacted with aggregate sector size. Standard errors are clustered by country. 
Appendix Table 1: Panel variation in labor market policies across European sample

\begin{tabular}{|c|c|c|c|c|c|c|c|c|}
\hline & \multicolumn{4}{|c|}{ Employment protection index } & \multicolumn{4}{|c|}{ Labor market expenditures share of GDP } \\
\hline & $1990-4$ & $1995-9$ & $2000-4$ & $2005-8$ & $1990-4$ & $1995-9$ & $2000-4$ & $2005-8$ \\
\hline & $(1)$ & $(2)$ & (3) & $(4)$ & $(5)$ & $(6)$ & $(7)$ & $(8)$ \\
\hline Austria & 2.2 & 2.2 & 2.1 & 1.9 & 1.6 & 1.9 & 1.9 & 2.0 \\
\hline Belgium & 3.2 & 2.6 & 2.2 & 2.2 & 3.9 & 3.8 & 3.4 & 3.4 \\
\hline Denmark & 2.4 & 1.5 & 1.5 & 1.5 & 6.3 & 5.1 & 4.3 & 3.1 \\
\hline Finland & 2.2 & 2.1 & 2.0 & 2.0 & 4.2 & 4.4 & 2.9 & 2.5 \\
\hline France & 3.0 & 3.0 & 3.0 & 3.1 & 2.5 & 2.7 & 2.7 & 2.2 \\
\hline Germany & 3.2 & 2.6 & 2.2 & 2.1 & 3.0 & 3.5 & 3.3 & 2.3 \\
\hline Ireland & 0.9 & 0.9 & 1.0 & 1.1 & 3.9 & 3.0 & 1.6 & 1.6 \\
\hline Italy & 3.6 & 3.2 & 2.0 & 1.8 & 1.2 & 1.3 & 1.2 & 1.3 \\
\hline Netherlands & 2.7 & 2.6 & 2.1 & 2.1 & 4.0 & 4.1 & 3.3 & 2.7 \\
\hline Norway & 2.9 & 2.7 & 2.6 & 2.7 & 2.3 & 1.6 & 1.4 & 1.1 \\
\hline Portugal & 3.9 & 3.7 & 3.6 & 3.4 & 1.1 & 1.4 & 1.7 & 1.8 \\
\hline Spain & 3.7 & 3.0 & 3.0 & 3.0 & 3.7 & 2.4 & 2.2 & 2.3 \\
\hline Sweden & 3.1 & 2.3 & 2.2 & 2.1 & 4.5 & 4.2 & 2.7 & 2.0 \\
\hline Switzerland & 1.1 & 1.1 & 1.1 & 1.1 & 1.0 & 1.8 & 1.4 & 1.3 \\
\hline \multirow[t]{4}{*}{ UK } & 0.6 & 0.6 & 0.7 & 0.8 & 1.5 & 0.8 & 0.6 & 0.5 \\
\hline & \multicolumn{4}{|c|}{ Labor market insurance levels index } & \multicolumn{4}{|c|}{ Labor market insurance mechanism index } \\
\hline & $1990-4$ & $1995-9$ & $2000-4$ & $2005-8$ & $1990-4$ & $1995-9$ & $2000-4$ & $2005-8$ \\
\hline & $(9)$ & $(10)$ & $(11)$ & $(12)$ & $(13)$ & $(14)$ & $(15)$ & $(16)$ \\
\hline Austria & 2.5 & 2.9 & 2.7 & 2.9 & 0.7 & 0.8 & 0.8 & 0.9 \\
\hline Belgium & 4.1 & 3.9 & 3.5 & 3.6 & 0.8 & 1.0 & 1.0 & 1.0 \\
\hline Denmark & 4.2 & 3.8 & 3.4 & 3.2 & 1.0 & 1.2 & 1.2 & 1.2 \\
\hline Finland & 3.6 & 3.9 & 3.2 & 3.2 & 1.0 & 1.1 & 1.0 & 1.0 \\
\hline France & 3.5 & 3.8 & 3.7 & 3.7 & 0.7 & 0.8 & 0.7 & 0.7 \\
\hline Germany & 3.8 & 3.9 & 3.4 & 3.2 & 0.7 & 0.9 & 1.0 & 0.9 \\
\hline Ireland & 3.0 & 2.9 & 1.9 & 2.2 & 1.3 & 1.3 & 1.2 & 1.2 \\
\hline Italy & 3.5 & 3.3 & 2.2 & 2.3 & 0.3 & 0.5 & 0.6 & 0.8 \\
\hline Netherlands & 3.8 & 4.1 & 3.4 & 3.3 & 0.9 & 1.0 & 1.0 & 1.0 \\
\hline Norway & 3.4 & 3.1 & 2.8 & 2.8 & 0.7 & 0.7 & 0.6 & 0.5 \\
\hline Portugal & 3.8 & 3.8 & 3.8 & 3.8 & 0.3 & 0.5 & 0.5 & 0.6 \\
\hline Spain & 4.4 & 3.7 & 3.5 & 3.7 & 0.7 & 0.8 & 0.7 & 0.7 \\
\hline Sweden & 4.2 & 3.9 & 3.2 & 3.0 & 0.8 & 1.0 & 0.9 & 0.9 \\
\hline Switzerland & 1.4 & 2.3 & 1.8 & 1.9 & 0.6 & 1.2 & 1.0 & 1.0 \\
\hline UK & 1.5 & 1.0 & 0.6 & 0.7 & 1.3 & 1.1 & 0.4 & 0.5 \\
\hline
\end{tabular}

Notes: See Table 1A. 
Communications - Internet Technology: browsers, portals, search engines and other internet enabling technologies, website design and consultancy, ISPs. Telecommunications (Hardware): voice and data communications equipment, cable/mobile/satellite network equipment excluding telecommunications carriers. Telecommunications (Carriers): cable/mobile/satellite telecommunications carriers. Communications (other): TV and radio broadcasting, media houses, publishing.

Computer Related - Computer (Hardware): computer mainframes, laptops, minicomputers, PDA/hand-held devices, optical scanning equipment, voice synthesis/recognition equipment. Computer (Semiconductors): semiconductors, electronic components (e.g., integrated circuits, transistors), semiconductor fabrication equipment. Computer (Services): data processing, hardware maintenance, IT consulting, IT training. Computer (Software): application software products, operating systems and systems-related software for all types of hardware, systems integration, software development. Includes manufacturers, resellers, and distributors.

Other Electronics Related - batteries, power supplies, fibre optics, analytical and scientific instrumentation.

Biotechnology - agricultural/animal biotechnology (e.g., plant diagnostics), industrial biotechnology (e.g., derived chemicals), biotechnology related research and production equipment.

Medical/Health Related - Medical (Healthcare): health institutions, hospital management, handicap aids \& basic healthcare supplies. Medical (Instruments/Devices): technologically advanced diagnostic $\&$ therapeutic products and services. Medical (Pharmaceuticals): drug development, manufacture and supply.

Energy - oil and gas exploration and production, exploration and drilling services and equipment, coal related, energy conservation related, alternative energy.

Consumer Related - Consumer (Retail): retailing of consumer products and services (including leisure and recreational products). Consumer (Other): manufacture and supply of consumer products.

Industrial Products and Services - industrial equipment and machinery, pollution and recycling related, industrial services.

Chemicals and Materials - agricultural chemicals, commodity chemicals, specialty or performance chemicals/materials, coating and adhesives, membranes and membrane-based products.

Industrial Automation - industrial measurement and sensing equipment, process control equipment, robotics, machine vision systems, numeric and computerized control of machine tools.

Other Manufacturing - business products and supplies, office furniture, textiles, hardware and plumbing supplies, pulp and paper, printing and binding, packaging products and systems.

Transportation - airlines, railways, buses, airfield and other transportation services, mail and package shipment.

Financial Services - banking, insurance related, real estate, securities and commodities brokers.

Other Services - engineering services, advertising and public relations, distributors, importers and wholesalers; consulting services (excluding IT consulting - see Computer: Services).

Agriculture - animal husbandry, crop cultivation, fishing, forestry.

Construction - construction services, manufacture of building materials, manufacture of pre-fabricated buildings and systems.

Other - mining, utilities, conglomerates.

Source: Compiled from EVCA Private Equity Survey Guidance Notes and Glossary by EVCA (2005), Thomson Financial, and PriceWaterhouseCoopers. We exclude the small EVCA sectors of Agriculture, Construction, and Other due to inability for calculating volatility. 
Appendix Table 3: Sector composition by country of European VC sample

\begin{tabular}{|c|c|c|c|c|c|c|c|}
\hline & Computers & $\begin{array}{c}\text { Comm- } \\
\text { unications }\end{array}$ & $\begin{array}{c}\text { Biotech- } \\
\text { nology }\end{array}$ & $\begin{array}{l}\text { Medical and } \\
\text { health }\end{array}$ & $\begin{array}{l}\text { Consumer } \\
\text { related }\end{array}$ & $\begin{array}{c}\text { Other } \\
\text { electronics }\end{array}$ & $\begin{array}{c}\text { Other } \\
\text { services }\end{array}$ \\
\hline & $(1)$ & $(2)$ & (3) & (4) & $(5)$ & $(6)$ & $(7)$ \\
\hline Austria & $28 \%$ & $11 \%$ & $14 \%$ & $7 \%$ & $7 \%$ & $10 \%$ & $6 \%$ \\
\hline Belgium & $28 \%$ & $17 \%$ & $14 \%$ & $8 \%$ & $8 \%$ & $6 \%$ & $4 \%$ \\
\hline Denmark & $20 \%$ & $15 \%$ & $24 \%$ & $18 \%$ & $5 \%$ & $7 \%$ & $2 \%$ \\
\hline Finland & $24 \%$ & $18 \%$ & $7 \%$ & $11 \%$ & $8 \%$ & $10 \%$ & $2 \%$ \\
\hline France & $26 \%$ & $22 \%$ & $8 \%$ & $7 \%$ & $14 \%$ & $7 \%$ & $6 \%$ \\
\hline Germany & $21 \%$ & $22 \%$ & $18 \%$ & $9 \%$ & $6 \%$ & $7 \%$ & $2 \%$ \\
\hline Ireland & $36 \%$ & $25 \%$ & $5 \%$ & $6 \%$ & $4 \%$ & $12 \%$ & $3 \%$ \\
\hline Italy & $11 \%$ & $19 \%$ & $2 \%$ & $6 \%$ & $18 \%$ & $4 \%$ & $8 \%$ \\
\hline Netherlands & $17 \%$ & $21 \%$ & $7 \%$ & $8 \%$ & $13 \%$ & $4 \%$ & $8 \%$ \\
\hline Norway & $23 \%$ & $20 \%$ & $7 \%$ & $8 \%$ & $5 \%$ & $4 \%$ & $4 \%$ \\
\hline Portugal & $10 \%$ & $6 \%$ & $4 \%$ & $11 \%$ & $28 \%$ & $4 \%$ & $10 \%$ \\
\hline Spain & $12 \%$ & $16 \%$ & $5 \%$ & $8 \%$ & $20 \%$ & $3 \%$ & $8 \%$ \\
\hline Sweden & $18 \%$ & $22 \%$ & $13 \%$ & $14 \%$ & $5 \%$ & $9 \%$ & $3 \%$ \\
\hline Switzerland & $15 \%$ & $18 \%$ & $21 \%$ & $17 \%$ & $4 \%$ & $13 \%$ & $1 \%$ \\
\hline \multirow[t]{3}{*}{ UK } & $23 \%$ & $21 \%$ & $8 \%$ & $12 \%$ & $10 \%$ & $7 \%$ & $6 \%$ \\
\hline & $\begin{array}{l}\text { Industrial } \\
\text { products }\end{array}$ & $\begin{array}{c}\text { Other } \\
\text { manufact. }\end{array}$ & $\begin{array}{l}\text { Financial } \\
\text { services }\end{array}$ & $\begin{array}{l}\text { Transport- } \\
\text { ation }\end{array}$ & Energy & $\begin{array}{l}\text { Chemicals } \\
\& \text { materials }\end{array}$ & $\begin{array}{c}\text { Industrial } \\
\text { automation }\end{array}$ \\
\hline & $(8)$ & $(9)$ & $(10)$ & $(11)$ & $(12)$ & $(13)$ & (14) \\
\hline Austria & $6 \%$ & $3 \%$ & $1 \%$ & $1 \%$ & $1 \%$ & $3 \%$ & $1 \%$ \\
\hline Belgium & $5 \%$ & $3 \%$ & $2 \%$ & $3 \%$ & $1 \%$ & $3 \%$ & $0 \%$ \\
\hline Denmark & $3 \%$ & $2 \%$ & $1 \%$ & $1 \%$ & $1 \%$ & $1 \%$ & $2 \%$ \\
\hline Finland & $7 \%$ & $3 \%$ & $1 \%$ & $2 \%$ & $2 \%$ & $2 \%$ & $3 \%$ \\
\hline France & $3 \%$ & $3 \%$ & $2 \%$ & $2 \%$ & $1 \%$ & $1 \%$ & $1 \%$ \\
\hline Germany & $3 \%$ & $2 \%$ & $1 \%$ & $3 \%$ & $2 \%$ & $2 \%$ & $2 \%$ \\
\hline Ireland & $1 \%$ & $2 \%$ & $1 \%$ & $1 \%$ & $0 \%$ & $0 \%$ & $3 \%$ \\
\hline Italy & $10 \%$ & $7 \%$ & $6 \%$ & $4 \%$ & $1 \%$ & $4 \%$ & $0 \%$ \\
\hline Netherlands & $4 \%$ & $4 \%$ & $4 \%$ & $3 \%$ & $2 \%$ & $1 \%$ & $2 \%$ \\
\hline Norway & $10 \%$ & $1 \%$ & $3 \%$ & $2 \%$ & $10 \%$ & $0 \%$ & $1 \%$ \\
\hline Portugal & $8 \%$ & $4 \%$ & $6 \%$ & $4 \%$ & $1 \%$ & $4 \%$ & $0 \%$ \\
\hline Spain & $5 \%$ & $5 \%$ & $3 \%$ & $7 \%$ & $3 \%$ & $3 \%$ & $1 \%$ \\
\hline Sweden & $4 \%$ & $2 \%$ & $1 \%$ & $2 \%$ & $1 \%$ & $1 \%$ & $4 \%$ \\
\hline Switzerland & $3 \%$ & $2 \%$ & $1 \%$ & $1 \%$ & $1 \%$ & $2 \%$ & $3 \%$ \\
\hline UK & $2 \%$ & $2 \%$ & $4 \%$ & $2 \%$ & $3 \%$ & $2 \%$ & $1 \%$ \\
\hline
\end{tabular}

Notes: See Tables 1A and 1B. Table documents the share of VC investment counts by country over 1990-2008 period.

Percentages for a country to sum $100 \%$ across the 14 columns. 